\title{
AANTEEKENINGEN OMTRENT DE GODSDIENSTIGE BEGRIPPEN DER KARO-BATAKS.
}

\author{
DOOR
}

\section{J. WESTENBERG.}

Weinige volken in den Indischen archipel zijn later met de Europeesche beschaving in aanraking gekomen, en hebben later de aandacht onzer onderzoekers en ethnografen getrokken dan de KaroBataks, oorspronkelijk de bewoners der hoogvlakte noordelijk van het Tobameer, van waar zij zich echter, vermoedelijk reeds vóor eeuwen, ook over de bovenstreken der aangrenzende kustlanden der tegenwoordige rijkjes Langkat, Deli en Serdang hebben verspreid.

Een klein deel van hen vermengde zich daar met de aan de kusten en langs den benedenloop der rivieren gevestigde Maleische elementen, eene vermenging waaraan de overgang van het heidendom tot den Islam onvermijdelijk was verbonden; de overgroote meerderheid bleef echter de zeden en gewoonten der vaderen getrouw en erkende, hoewel niet zonder tegenstand, tot zekere hoogte de souvereiniteit der Maleische sultans of pangerans en het eenigszins meer krachtige gezag der Datoe's, die, oorspronkelijk van vorstelijk Bataksche afkomst, maar tot den Islam overgegaan, de natuurlijke en invloedrijke tusschenpersonen waren tusschen de Bataksche bevolking der binnenlanden en de Maleische kustbewoners.

Met het moederland, de hoogvlakte, werden door deze Bataksche kolonisten steeds zeer levendige betrekkingen onderhouden, en indien men de Karo-Bataks langzamerhand ook ging onderscheiden in Kalak goenoeng (bergmenschen) en Kalak doesoen (doesoenmenschen), deze verdeeling berustte uitsluitend op de woonplaatsen, geenszins op eenig gewichtig onderscheid in voorkomen, adat of begrippen. 1

' Uit het hier gezegde begrijpt men gemakkelijk wat men moet verstaan onder de benamingen Doesoen en Doesoen-Bataks, die in het vervolg van dit opstel hier en daar voorkomen. Vergl. voorts de Nota over de onafhankelijke Bataklanden, 
Intusschen wisten de Nederlandsche ethnografen nawwelijks of in het geheel niet dat in deze verwijderde streken een talrijke Batakstam werd aangetroffen, die naast vele aanrakingspunten ook groote verschillen vertoonde met de beter bekende Mandailingers en Tobas.

Het was toch gedurende langen tijd bijna uitsluitend van de Westkust uitgaande dat het Nederlandsch-Indische Gouvernement den kring van zijn gezag en zijn invloed in Sumatra's binnenlanden poogde uit te breiden. Eerst veel later bracht onze vestiging ter Oostkust, vooral in Deli, ons eindelijk met de Oostelijke Bataks, de orang Timor, en met de meer Noordelijk wonende orang Karo in aanraking. Van daar dan ook dat omtrent de Tobas reeds tal van inlichtingen waren verkregen, en reeds tal van schrijvers, met den beroemden Junghuhn aan het hoofd, belangrijke bizonderheden omtrent hen hadden meêgedeeld, toen nog niemand aan de KaroBataks dacht.

Wel is er in den laatsten tijd eene merkbare verandering ten goede gekomen, zijn ook de onafhankelijke Karo- en Timorlanden ten deele door verschillende reizigers doorkruist, en telt de ethnografie dier streken, vooral in het Delische, enkele belangstellende beoefenaars; maar tegenover de talrijke geschriften betreffende de meer Westelijke stammen maakt het weinige dat over Karo- en Timor-Bataks in druk verscheen, ten minste wat de hoeveelheirl bctreft, nog steeds een weinig schitterende figuur. Geldt dit in het algemeen, het geldt ook in het bizonder voor het onderwerp aan het hoofd van dit opstel aangeduid. Toch is het niet dan na lange aarzeling dat ik het waag mijne aanteekeningen omtrent de godsdienstige begrippen der Karo-Bataks reeds thans aan te bieden. In de berichten die ik mij kon verschaffen bleven nog veleleemten, sommige punten bleven nog duister, omtrent andere zijn de mij geworden inlichtingen nog oppervlakkig en onvolledig: kortom, het is er nog verre van dat ik het door mij betreden gebied in alle richtingen heb doorkruist en het dus in al zijne uitgestrektheid kan behandelen. In groote trekken meen ik echter het beeld van het land reeds thans met tamelijke nauwkeurigheid te kunnen teekenen en al zal hier en daar wellicht eene lijn verkeerd loopen, niets belet later die fout te herstellen en tevens bij te schetsen wat er nog ontbreekt. Want zoo ergens, dan geldt op het gebied der ethnografie

door den heer W. geplaatst in Tijdschr. v. h, Bat. Gen. Dl. XXXIV blz. 105 en de kaarten, begoorende bij de berichten van den zendeling H. C. Kruijt in de Meded. v. h. Nederl. Zendelinggenootschap Dl. XXXIV bl. 325 en Dl. XXXV blz. 309 . 
dat men het ijzer moet smeden, terwijl het heet is. Zelfs de uitgebreidste en zorgvuldigst verzamelde aanteekeningen hebben nog aanvulling noodig, en die aanvulling is slechts te verkrijgen waar de aanteekeningen ontstonden, in het land en onder het volk welke de studie geldt.

De belangrijkste mededeelingen op dit gebied dankt men zeer zeker aan Dr. B. Hagen, wiens opstel: Beiträge zur Kentniss der Battareligion eene plaats vond in deel XXVIII, aflevering 6, van het Tijdschrift voor de Indische Tual-, Land- en Volkenkunde. In dat opstel vindt men tal van wèl niet altijd even juiste, maar toch over het algemeen zeer belangwekkende bizonderheden. Van de onjuistheden kan men trouwens den geachten schrijver moeilijk een ernstig verwijt maken, daar de mondelinge berichten der bevolking, waarop elk onderzoeker op ethnografisch gebied wel in hoofdzaak moet afgaan, dikwijls tegenstrijdig en weinig vertrouwbaar blijken, zoodat eene nauwkeurige zifting der ingewonnen berichten eene eerste vereischte is. Wil men die zifting met goed gevolg volbrengen, dan moet men zich eerst vertrouwd hebben gemaakt met het karakter, de begrippen en de denkwijze van het volk, waartoe men met den besten wil van de wereld zonder onder dat volk gevestigd te zijn, en er dagelijks en vertrouwelijk meê om te gaan, niet kan geraken. Men komt er zoo licht toe aan de verhalen van een enkel misschien leugenachtig of slecht ingelicht individu veel meer waarde te hechten dan daaraan toekomt.

Een voorbeeld slechts. Op mijne vragen omtrent de begrippen, die de Karo-Bataks zich betrekkelijk een toekomstig leven vormen, kreeg ik, vooral wanneer ik eenigszins aandrong, herhaaldelijk een antwoord waarin van swarga en naraka werd gesproken. Oppervlakkig zou men dus tot het besluit komen dat de Bataks aan een hemel en een hel gelooven, maar ging ik dieper op het onderwerp door, dan bleek het al heel spoedig dat de berichtgevers niets deden dan de Maleiers napraten, bij wie deze woorden nu eenmaal burgerrecht hebben gekregen.

Ik acht het niet alleen hoogst waarschijnlijk, maar zelfs zoo goed als zeker dat de berichten van Dr. Hagen omtrent het vereeren door de Bataks van de goden Nabi Mohammed en Padi Allah op denzelfden zwakken grond berusten. Dr. Hagen zegt daaromtrent: "Den beiden letzten Göttern ist ihr islamitischer Ursprung deutlich genug auf die Stirn geschrieben und ihre Verehrung selbst im Herzen von Tobah am gleichnahmigen See beweist das unaufhaltsame Vordringen des Mohamedanismus unter den Batta's." 
Het schijnt niet twijfelachtig, dat de mededeelingen die dr. Hagen tot deze beschouwing aanleiding gaven uit den koker kwamen hetzij van een Batak die zelf lang onder de Maleiers verkeerd en hunne denkbeelden ten deele overgenomen had, hetzij van een Tobanees die, wel eens iets van Allah en van Mohamed gehoord hebbende, zijne geleerdheid tegenover den vreemdeling wilde luchten.

Feitelijk is van een "Vordringen des Mohamedanismus" in de doesoens der Maleische rijkjes, laat staan "im Herzen von Tobah" (of liever in de streken die dr. Hagen bedoelt en met die benaming minder juist aanduidt) al zeer weinig te bespeuren. In vroegere tijden heeft de Islam in die doesoens zeer zeker wel vorderingen gemaakt, zelfs aanzienlijke vorderingen ook, maar die beweging kwam sinds jaren tot bijna algeheelen stilstand en tegenwoordig is de godsdienst der Maleiers onder de heidensche Bataks even impopulair als hun gezag. Herhaaldelijk zag ik zelfs voorbeelden dat pensonen, die vroeger de leer van Mohamed hadden ađngenomen, weêr terugkeerden tot het heidendom.

Een gewichtiger bezwaar, dat tegen het opstel van dr. Hagen aangevoerd kan worden, is dat het aanleiding geeft tot verwarring, in zoover als de geachte schrijver de godsdienstige meeningen van verschillende stammen als Toba-, Timor- en Karo-Bataks niet genoeg gescheiden houdt en dan ook van eene "Battareligion" spreekt, eene uitdrukking die door hare algemeenheid geheel onjuist is.

Bij de verschillende Batakstammen treft men in dit opzicht wel degelijk groote verschillen aan, hoewel minder in de algemeene beginselen, in de richting van het zieleleven, dan in bizonderheden, in namen ên overleveringen. Hierbij moet in aanmerking worden genomen dat de Karo-Bataks beweren tot de Toba- en Timor-Bataks slechts in verwijderde betrekking te staan, maar daarentegen rechtstreeks af te stammen van de menschenvleeschlievende Pakpak in de Bovenlanden van Singkel.

Dr. Hagen schijnt zijne inlichtingen uit Toba- en vooral uit Timor-bronnen te hebben verkregen en niet te hebben geweten, dat de Karo-Bataks in bijna alle opzichten afwijkende voorstellingen huldigen. Van de drie hoofdgoden die hij noemt: Batara Goeroe, Sori en Balaboelan, zijn de beide laatsten bij de Karo-Bataks, niet alleen bij den kleinen man en bij de hoofden, maar zelfs bij de grootste goeroes geheel onbekende grootheden, om van Nabi Mohammed en Padi Allah niet te spreken. Hetzelfde is het geval met ongeveer alle namen die in dr. Hagen's opstel voorkomen. 
Ten einde deze klip te vermijden, ben ik bij het verzamelen dezer aanteekeningen uitsluitend met Karo-Bataks te rade gegaan. Mijn voornaamste zegsman was daarbij de nu sedert ongeveer een half jaar overleden goeroe Si Beleilei van Ketangkoehan in Soekapiring, die niet alleen onder de Doesoen-Bataks, maar eveneens onder de bewoners der hoogvlakte een grooten naam had van kunde, macht en geleerdheid. Zijne berichten werden door mij steeds zoo nauwkeurig mogelijk getoetst aan die van verschillende goeroes, hoofden en andere ontwikkelde Bataks.

In het godsdienstige leven van het volk der Karo-Bataks moet men twee hoofdelementen nauwkeurig onderscheiden, hoofdelementen waartusschen bijna elk onderling verband ontbreekt.

In de eerste plaats treffen wij eene soort mythologie aan van waarschijnlijk Hindoeschen of ten minste buitenlandschen oorsprong.

Deze mythologie, door mondelinge overleveringen en wellicht door enkele geschriften (poestaka) in sommige goeroe-geslachten bewaard, weet te verhalen van eene geheele reeks goden en godinnen, van de schepping der wereld en van den legendairen oorsprong van verschillende natuurverschịnselen. Niet alleen het eigenlijke volk, maar ook de groote massa der hoofden is aan deze overleveringen vreemd en heeft er zelfs nooit van hooren spreken dan zeer frag. mentarisch in enkele toover- en bezweringsformules, door de goeroes bij plechtige gelegenheden opgedreund.

Practisch stoort niemand zich aan deze goden, noch laten de Bataks zich door de gedachte aan en de vrees voor hen van eenige daad terughouden, uitgezonderd wellicht van meineed. Niet dat de massa der Bataks zoo weinig liberaal is om daartegen op te zien. Verreweg de meeste hunner zijn bereid voor enkele dollars alles te zweren wat men verkiest, maar in theorie zijn het toch zeer zeker de goden (débata) die den meineed straften, al worden zij bij den gebruikelijken, hoogst eenvoudigen eedsvorm ook niet rechtstreeks aangeroepen. Zeer waarschijnlijk was deze eeredienst vroeger veel algemeener verspreid, waarbij zich twee mogelijkheden voordoen:

ten eerste, dat het plateau van Toba vroeger door een ander volk werd bewoond, dat om de eene of andere reden te gronde ging en door de van elders gekomen Bataks werd verdrongen, waarbij die Bataks enkele van de mythen der verdrevenen overnamen;

ten tweede, dat het Batakvolk een tijd lang moest bukken onder vreemde overheerschers die hun eigen godsdienst op het plateau 
verbreidden tot tijd en wijle de Bataks het juk afwierpen en de vreemdelingen verjoegen, waardoor tevens de van elders ingevoerde eeredienst meer en meer in verval raakte.

De laatste theorie luidt zeker niet onwaarschijnlijk. In allen gevalle kan men zeer zeker gerust aannemen, dat de mythologische verhalen, bij de goeroes bewaard, van vreemden oorsprong zijn, en daarentegen de nog ten huidigen dage zoo algemeene vereering van de geesten der voorouders en van andere afgestorvenen als bij zoovele andere natuurvolken ook bij de Karo-Bataks de eenig oorspronkelịke eeredienst uitmaakte.

Eene zwakke verbinding tusschen deze beide godsdienstige elementen, de ingevoerde mythologie en de oorspronkelijke vereering der geesten, wordt gevormd door de bovenbedoelde oude tooverformules, waarvan dikwijls gebruik wordt gemaakt bij plechtigheden die geheel op het oude geestengeloof berusten, en verder door enkele verhalen en overleveringen, waarin van den invloed van beide elementen sporen worden aangetroffen.

Wat enkele goeroes mij omtrent het meer en meer verloren gaande polytheisme wisten te vertellen, komt in hoofdzaak op het volgende neêr.

In de allereerste tijden, lang vóor de schepping der aarde, waren er slechts twee godheden: Ompong batara goeroe di atas, zetelende in wat wij den hemel zouden noemen, en Ompong débata Teroeh die in de benedenwereld den scepter voerde. ${ }^{1}$

De schoone dochter van dezen Indischen Pluto was door Ompong batara goeroe di atas tot gemalin verheven, en door hem naar zijn wolkenrijk meêgevoerd. De beide echtgenooten konden het best met elkaâr vinden en voerden een idyllisch leven, al te idyllisch zelfs, in zoover als de lasten en zorgen van de zwangerschap der vorstin langer bespaard bleven als zij zelve en haar man wel wenschelijk achtten. Toen hun huwelijk zoo vier jaren had geduurd en nog

1 In dit opstel is de letter $e$ doorgaans zonder toonteeken geschreven en slechts enkele malen van het teeken $\Delta$ voorzien. Dit laatste is duidelijkheidshalve weggelaten waar het voorkwam, bijv. op het woord têndi, dat echter door den schrijver veelal met tendi getranscribeerd is. In het Tobasch is het tondi. Daar de $o$ van het Tobasch in het Dairisch dialect gewoonlijk in eene toonlooze $e$ verandert en het Karo-Bataksch in zoovele opzichten met dit dialect overeenkomt, zal men deze letter hier wel bijna overal evenzoo moeten uitspreken. Woorden zooals debata en begoe en nog een paar andere zullen hier echter zeker met een zacht-lange $e$, zooals bijv. in ons woord abezig» worden uitgesproken, weshalve die van een accent aigu zijn voorzien (bégoe, débata). Slechts omtrent zeer enkele woorden in dit stuk kan twijfel bestaan nl. omtrent de uitspraak der e. Of debata ook bij de Karo's den klemtoon op de laatste lettergreep heeft, zooals bij de Tobas, is nog niet bekend. 
altijd geenerlei teekenen de naderende geboorte van eene godenspruit voorspelden, liet Batara Goeroe het hoofd hangen en verviel tot de zwartste misanthropie. Het luie en lekkere leven, zoolang door hem gevoerd, werd hatelijk in zijn oog; hij besloot afstand te doen van al die niet langer gewaardeerde heerlijkheden, en in de ontberingen van een kluizenaarsleven rust te zoeken voor zijn ontstemd gemoed.

Zoo gezegd, zoo gedaan. In oude, afgedragen kleederen gehuld, niets meênemende dan enkele landbouwgereedschappen en ietwat rijst om onder weg hun honger te stillen, verlieten Batara Goeroe en zijne gemalin het schouwtooneel hunner onbekroonde huwelijksvreugde, om ergens aan het strand der zee (zeker eene hemelsche zee, want, zooals gezegd bestond de aarde nog niet) een hutje te bouwen. In die nederige woning brachten zij nu hunne vrije uren door, het grootste deel van hun tijd wijdende aan den aanleg van eene fraaie ladang, die zij met meer zin voor natuurschoon dan voor practisch nut met allerlei fraaie bloemen beplantten.

Zij zouden echter niet veel voldoening van hun arbeid hebben.

Op een goeden middag toen zij onder het bescheiden atapdak van hun huisje sliepen, verrees er uit den oceaan een kolossaal monster, eene zeeslang, Toemoeldang di bosi geheeten, die zonder den minsten eerbied voor Batara Goeroe's hooge waardigheid de heele ladang omwoelde en alle bloemen opvrat, waarna hij op zijne beurt tot bevordering zijner digestie eene siesta ging nemen.

Bij het ontwaken werd Batara Goeroe met evenveel schrik als verontwaardiging de verwoesting van zijn bloemenhof gewaar, en in de verte den draak bespeurende, zond hij terstond een djoewa (hoeloebalang) uit om het ondier te dooden. De djoewa vond de hem opgedragen taak maar half aardig en achtte het, na Toemoeldang di bosi's eerbiedwaardig gebit en geweldigen lichaamsbouw op eenigen afstand te hebben opgenomen, veel raadzamer, alvorens tot dadelijkheden over te gaan, den weg der onderhandelingen in te slaan.

Hij begon dus met de slang wegens zijn hoogst lakenswaardig gedrag om inlichtingen te verzoeken.

Het in zijn middagrust gestoorde monster zag den lastigen vrager alles behalve vriendelijk aan en maakte reeds eenige happende bewegingen, terwijl het brommend antwoordde, dat Batara Goeroe de geheele ellende aan zich zelven had te wijten, daar het hoegenaamd niet te pas kwam voor een zoo machtigen vorst om als een arme stakkert van een landbouwer zelf eene ladang te gaan bewerken en zoo zijne waardigheid met voeten te treden. Hij verklaarde grooten 
lust te hebben om zijn bloemendéjeuner met het nuttigen van den djoewa te besluiten en slechts van dat smakelijk brokje afstand te zullen doen, als de djoewa beloofde met den uitersten spoed Batara Goeroe en diens gemalin te zullen roepen, met welke hij een appeltje had te schillen. De vorst zou wijs doen daarbij een goed aantal pisangs en een ffinken schotel boemboeën (een soort geestenvoedsel, bestaande uit padi, ei, sirih, pisang, enz.) meê te brengen. De djoewa had geene herhaling van dit bevel noodig om met den uitersten spoed huiswaarts te keeren. Hij bracht de boodschap getrouw aan zijn meester over die, onbevreesd van aard, de pisang en de boemboeën in orde bracht, en daarop in gezelschap van zijne echtgenoote Toemoeldang di bosi ging opzoeken.

Batara Goeroe opende het gesprek en klaagde over de alles ' behalve nette manier waarop zijn geëerde gast in zijn rijk was gekomen. Doch Toemoeldang di bosi liet zich daardoor niet van zijn stuk brengen.

"Edele vorst," zeide het monster, "wat ik heb gedaan was niet "meer dan mijn plicht. Ge verdiendet nog erger lot, want ge hebt "zeer gezondigd door niet te zorgen voor de behoorlijke voortplanting "van uw geslacht."

"Ge hebt mooi spreken," antwoordde Batara Goeroe. "Geloof me, "het heeft niet aan mijn goeden wil gelegen. Als ge er intusschen "iets op weet, houd ik me ten zeerste anbevolen."

De slang verklaarde gegronde hoop te hebben de zaak in orde te kunnen brengen, mits Batara Goeroe zijn raad getrouw opvolgde.

"Begin maar eens," vervolgde het monster, "met de pisangs en "de boemboeën die gij hebt meêgebracht in mijn muil te stoppen."

Doch dit voorstel lachte den god slechts matig toe en scheen hem erg naar eene krijgslist te rieken.

"Grootvader," zeide hij tot de slang, "uw muil is wel zeven "esta's wijd, en voorzien van een zoo fraai en zeer scherp gebit dat "ik ril wanneer ik er maar naar kijk. Neem me dus niet kwalijk "als ik tegen uw voorstel eenige bescheiden bedenkingen heb." ${ }^{1}$

Verre van zich geërgerd te betoonen, verklaarde Toemoeldang di bosi zich gaarne bereid aan dit wantrouwen tegemoet te komen.

"Neem uw zwaard," zeide hij, "en plaats het rechtstandig tus/schen mijne kaken. Dan kan ik mijn mond niet sluiten en kunt

\footnotetext{
1 Het woord esta is hier wel = het Tobasch, hasta, dat voIgens het Woordenb. van Dr. v. d. Tuuk beteekent ade lengte van den voorarm als maat gebezigd » (vgl. het Sanskr., Mal. enz. hasta.)
} 
"ge onbevreesd voor eene niesbui of onwillekeurige beweging mijner"zijds uwe hand naar binnen brengen."

Batara Goeroe vond dit denkbeeld lang niet kwaad; hij plaatste het zwaard tusschen de opgesperde kaken en bracht daarop de meêgebrachte spijzen in den muil van het ondier.

Toen hij zijne hand terugtrok, zat er een ring aan een der vingers.

Batara Goeroe zag dit met verbazing en haastte zich het zwaard terug te nemen en daardoor Toemoeldang di bosi gelegenheid te geven zijne vragen te beantwoorden.

"Kijk eens, grootvader, die ring is mij daarbinnen aan den vinger "geschoten, waar dient die voor?"

"Wel, dat is eene sinsing pinta pinta (wenschring). Nu kunt ge "vragen wat ge wilt, een zoon, of eene dochter, of varkensvleesch, of "paula (palmwijn) of wat ook, en ge zult uw wensch vervuld zien."

De god en zijne vrouw waren over dit buitenkansje niet weinig verheugd en begonnen van vreugde te tandakken. Toen zij watkalmer waren geworden, legde Toemoeldang di bosi hum uit hoe zij den ring moesten gebruiken, en nam daarop een hartelijk afscheid. Een oogenblik later was hij in de golven verdwenen.

Met een verlicht gemoed verlieten de echtgenooten nu hunne kluis en togen weêr naar de vorstelijke woning. Toen het volle maan was, poetste de god volgens de instructiën van hunnen weldoener den ring met limoensap en wenschte zich een zoon, die dan ook negen maanden later op natủurlijke wijze ter wereld kwam. Hij herhaalde die handeling verscheidene malen en kwam in het bezit van drie zoons en twee dochters.

De zoons heetten:

10. Padoeka di adji, die in de benedenwereld bij zijn grootouder ging wonen.

20. Toean Benoewa Koling, schepper van deze aarde. bleef.

30. Toean Radja Samsei Sahinahina, die boven bij zijn vaders

De dochters waren :

10. Toean Benoewa Katji, die in de buurt woont waar de zou opgaat en naar welke de gebeden der Bataks gaan.

20. Toean Radja Mangili Boenga (misschien dezelfde als de Mangala Boelan waarvan dr. Hagen spreekt?) wonende waar de maan opgaat en, volgens de Bataks, degene die hoort naar de gebeden der Maleiers.

Toean Benoewa Koling werd de schepper van deze aarde, die hij 
vervasrdigde van zeven handenvol aarde, en die vervolgens door Batara Goeroe met een zijden draad aan den hemel werd opgehangen,

Daar dit nieuwe hemellichaam intussehen in de benedenwereld eene groote duisternis veroorzaakte, zoodat men er geen hand voor de oogen meer kon zien, werd Padoeka di adji, die dauronder zijn woning had opgeslagen, zeer vertoornd en deed door het veroorzaken van hevige stormen de schepping van zijn broeder zeven malen mislukken.

Toean Benoewa Koling beklaagde zich bij hun gemeenschappelijken vader, en toen deze zag hoe zijne berispingen en vermaningen hoegenaamd niets baatten, besloot hij tot krachtiger mastregelen over te gaan.

Terwijl Padoeka di adji sliep, kwam Batara Goeroe nasr beneden, en maakte boven den weerspannigen zoon een grooten ijzeren rooster (besi maléla), bestaande uit vier kruiselings geplastste staven, waarvan de acht uiteinden naar de voornasuste windstreken waren gericht. In de richting dier uiteinden lagen volyzus de overlevering fabelachtige rijken, die bestuurd werden door afstammelingen der goden.

Die rijken zijn, gerekend van het Oosten door het Noorden naar het Westen en Zuiden :

Poerba (Oost).

Agoeni (Noord-Oost).

Irissen (Noord).

Pestima (Noord-West).

Daksina (West).

Narita (Zuid-West).

Mangabia (Zuid).

Nariti ('Zuid-Oost).

Ook de aarde werd door Batara Goeroe hersteld en geheel vlak gemaakt.

Maar toen Padoeka di adji uit zijn slaap ontwaakte, zich eens uitrekte en wilde opstaan, schudden de besi maléla en de aarde daarboven op zulk eene wijze dat allerwege bergen en valleien ontstonden. Intusschen, de besi maléla was liecht en sterk, en ondanks alle later ondernomen pogingen gelukte het den gevangene niet zich te bevrijden. Tot op den huidigen dag ligt hij onder zijn rooster, en wanneer hij nu en dan kwaad wordt en beproeft rich aan den ijzeren greep te ontworstelen, beeft deze aarde.

Is dus Padoeka di adji een lastig en kwaadaardig machthebbende, 
aan wien noch het menschdom, noch zijne familie veel genoegen beleeft, Toean Benoewa Koling houdt op deze aarde alles gaande, en zorgt voor den plantengroei, enz., terwijl Toean Radja Samsei Sahinahina van boven uit over den regen beschikt en hunne beide zusters, zooals reeds gezegd, verondersteld worden een aandachtig oor te leenen aan de gebeden respectievelijk van Bataks en niet-Bataks.

Het scheppingsverhaal, opgenomen in het reisverslag van den heer de Haan (Verhandelingen van het Bataviaasch Genootschap, deel XXXVIII) komt met het door mij meêgedeelde in menig opzicht overeen. Omtrent de geheimzinnige kip, waarover de schrijver spreekt en nit wier bloed, veêren, enz. het water, de planten, enz. zouden zijn ontstaan, werd mij eene eenigszins afwijkende legende meêgedeeld, die tevens eenige opheldering geeft over de wijze waarop Batara Goeroe aan zijne vrouw kwam.

De vader der goden was namelijk indertijd een zeer bescheiden jongeling, die ondanks het aandringen zijner onderdanen er maar niet toe wilde overgaan eene vrouw te nemen, omdat hij, als hebbende nog nooit iets werkelijk fraais tot stand gebracht, zich den echtelijken staat niet waardig achtte. Daar het leven van vrijgezel hem echter op den duur verveelde en hij bovendien gaarne het verlangen zijns volks te gemoet wilde komen, besloot hij een kunstwerk te vervaardigen dat hem in ieders oog recht zou geven op de genietingen der huwelijksvreugde. Hij toog dus aan den arbeid en vervaardigde een fraaien gouden vogel, dien hij vervolgens den volke vertoonde vragende of de man die tot zulk een arbeid in staat was niet met recht een groot vorst kan worden genoemd. Zijne onderzaten deelden deze eenigszins v reemde opvatting van de hoedanigheden die aan een vorst het kenmerk van grootheid geven. Geheel voldaan waren zij echter nog niet. Het beest was wel heel mooi, maar het miste twee voorname eigenschappen van een vogel: het kon noch zingen, noch vliegen.

Doch ook daarop wist de god raad. Hij deed den vogel in een grooten pot in gezelschap van een massa krekels en liet hem daarin tot hij behoorlijk vliegen en zingen had geleerd. Het volk was nu opgetogen en Batara Goeroe haastte zich den vogel, Manoek Sinanggoer dawa dawa als gezant naar de onderwereld te zenden, waar hij de hand van Si Beroe Poeang Sinder Mataniari voor zijn meester wist te verwerven. Met den vogel echter liep het treurig af; want toen, na het ontstaan der aarde, het dier zich niet ontzag den vijver van Toean Benoewa Koling herhaaldelijk te bevuilen, sloeg deze hem dood en deed uit zịnn veêren, lichaam, enz. allerlei 
geneeskrachtige planten als: salindjoeang, simampiren, enz. ontstaan

Het scheppingsverhaal, door dr. Hagen opgenomen in het rapport zijner in December 1883 gedane reis naar het Tobameer, heeft mijns inziens weinig waarde, te minder omdat Nabi Mohammed er eene rol in speelt. Een enkele Batak moge zich vermaken met, onder den invloed van een verblijf in Mahomedaansche landen, zulk een sprookje te vertellen; dat het een beeld zou geven van het oude volksgeloof is eenvoudig onaanneemlijk. De gezamentlijke godheden worden naar hunne woonplaatsen onderscheiden in débata di atas, débata di tengah en debata di teroeh) beneden), onder welke benaming zij bijna uitsluitend worden aangeroepen en bij het volk uit de gezangen der goeroes bekend zijn. Welke godheden tot elk dezer categoriën worden gerekend, volgt uit het bovenstaande van zelf.

Dit is in hoofdzaak wat ik tot nu toe over het Bataksche polytheisme te weten heb kunnen komen. Hoogstwaarschijnlijk zijn er vroeger meerdere overleveringen, zich bij deze hoofdmythe aansluitende, in omloop geweest en zullen sommigen daarvan nog wel hier en daar in enkele goeroefamilies bewaard zijn gebleven. Een bewijs daarvan vond ik in het verhaal van den tooverstok van den goeroe Beleilei, dat ik hieronder meêdeel.

De oorspronkelijke beteekenis van het woord débata (ook wel nebata) is voor de Bataks zeer zeker god, godheid. Toch verstaan zij er bovendien uog iets anders onder. Débata di atas noemen de Bataks niet alleen de in eene denkbeeldige bovenwereld vertoevende godheden, maar ook die bovenwereld zelve. Op dezelfde wijze wordt deze aarde débata di tengah, de onderwereld débata di teroeh genaamd. De débata di atas zou bevolkt zijn door menschen, die de maag in den hals, de débata di teroeh door menschen die de maag in de kuiten hebben.

De mededeelingen omtrent die fabelachtige lieden dragen echter geheel het karakter van volkssprookjes, en staan waarschijnlijk met de oorspronkelijke godenleer in geen verband.

Veel meer dan over deze Indisch getinte, polytheistische leer kan medegedeeld worden over de vereering der afgestorvenen, vooral der voorouders, eene vereering die met het geheele bestaan der Bataks innig is saamgeweven en bij elke plechtigheid, bij elk bijgeloof, bij elke ramp of gewichtige gebeurtenis om den hoek komt kijken.

Van eenige zedelijke verheffing, van voorschriften omtrent een goeden en rechtvaardigen levenswandel, van waarschuwing tegen 
het kwade, ja zelfs van eenig onderscheid maken tusschen goed en kwaad is ook bij dezen "Ahnendienst," niets te bespeuren.

De grondslagen van het stelsel, wanneer men deze weinig ingewikkelde begrippen een stelsel noemen wil, zijn hoogst eenvoudig en van zeer cynischen en plat prozaischen aard.

In het kort komen zij op het volgende neêr.

De zielen der afgestorvenen blijven onder den algemeenen naam bégoe op deze aarde ronddwalen. Meest zijn zij onzichtbaar, doch het staat in hun vermogen in de menschen te varen, geheel dus volgens de spiritistische leer der mediums, terwijl zij zich ook wel een enkelen keer in dezelfde gedaante als hun vleeschelijk omhulsel eenmaal droeg aan de levenden vertoonen. Hoewel geesten, hebben de bégoe's geenszins afstand gedaan van alle stoffelijke begeerten. Integendeel steeds hebben zij honger en dorst, en voorzien de achtergebleven bloedverwanten niet van tijd tot tijd door offers in hunne behoeften, dan wreken zij zich door de schuldigen met ziekten, kwalen en rampen te bezoeken. Slechts een flinke maaltijd kan hen verzoenen. Andere bégoe's hebben het minder bepaald op hun nagelaten betrekkingen voorzien, maar vallen ieder aan die hen op eenige wijze, bijvoorbeeld door het betreden van hun gebied, beleedigt.

Doch al kiezen zij andere slachtoffers, het doel waarnaar zij streven is hetzelfde, een offer van eene geit, eene kip, rijjst, pisang, sirih en vooral veel palmwijn.

De Batak, die de geesten voldoende spijzigt, is van een godsdienstig standpunt beschouwd een braaf man. Moge hij verder een dief zijn, een moordenaar en een brandstichter, zoo zal hem dit wellicht de wereldsche gerechtigheid op den hals halen, doch de geesten laat het koud. Zij toch raadplegen slechts de belangen hunner magen. Zijn die gevuld, dan is alles pour le mieux dans le meilleur des mondes. Dat dergelijke godsdienstige begrippen op de moraliteit en het karakter van een volk slechts een nadeeligen, nimmer een heilzamen invloed vermogen uit te oefenen, ligt voor de hand. Het zou dan ook moeielijk zijn nationale deugden der Karo-Bataks op te noemen of men moest vroolijkheid en spraakzaamheid, zekere aan koppigheid grenzende volharding bij de verdediging hunner belangen, en een uit onbekendheid met de waarde van den tijd voortspruitend geduld als deugden beschouwen; daarentegen strekken hunne vele ondeugden dikwijls om elkaâr te neutraliseeren, en is vooral hunne groote lafhartigheid een machtige drawback, die hen 
menigmaal terughoudt van misdaden, welke zij anders zonder eenig gemoedsbezwaar zouden plegen.

Hierboven heb ik de geesten der afgestorvenen bégoe genoemd. Tk gebruikte dat woord daar slechts in eene algemeene beteekenis.

De Batak toch onderscheidt bij die geesten verschillende klassen, en slechts eene dier klassen, trouwens zooal niet de belangrijkste, dan toch verreweg de nitgebreidste, wordt door hem steeds als bégoe vermeld.

Men kan de geesten der afgestorvenen onderscheiden in :

10. Bitjara goeroe;

20. Matei sadawari;

30. Toengkoeb;

40. Bégoe.

Van anderen oorsprong en geaardheid zijn :

10. De Hantoe;

20. de Omang;

40. de Orang boenian,

welke drie klassen van geheimzinnige wezens $i k$ in het vervolg zal behandelen.

Onder bitjara goeroe verstaat de Karo-Batak de geesten van kinderen die dood ter wereld kwamen (hetzij tijdig of ouvoldragen) of die stierven vóór het tanden krịgen.

Dr. Hagen noemt deze geesten Batara goeroe, neemt aan, dat zij homogeen zijn met den gelijknamigen God van het Bataksche polytheisme, en leidt daaruit tamelijk verreikende gevolgtrekkingen af.

$1 \mathrm{k}$ voor mij heb in de Karolanden die kindergeesten steeds bitjara goeroe hooren noemen, en van eenig verband tusschen hen en den hemelgod wist niemand mij iets te vertellen.

De stelling van den heer Hagen, gegrond op de waarschijnlijk toevallige gelijkluidendheid van twee namen, komt mij dan ook tamelijk gewaagd voor, te meer daar de oorsprong der uitdrukking bitjara goeroe niet ver te zoeken is. Wel is waar beteekent bitjara in het Bataksch meer speciaal adat, de uitspraken der adat, maar toch kan aan bitjara goeroe best eene zekere beteekenis worden toegekend, wanneer men in het oog houdt dat deze geesten, steeds sprekend, hunne uitspraken doen door den mond der goeroes (priesters). De naam verklaart zich dus van zelf, evenals dat het geval is met de uitdrukking matei sadawari (in één dag en dus plotseling gestorvenen).

Men moet evenwel niet meenen dat elk kind, dat in de boven5 Volg. VII. 
genoemde omstandigheden sterft, daarom later als bitjara goeroe wordt vereerd. Of zulks al dan niet geschiedt, zal grootendeels daarvan af hangen of de familieleden van het schepseltje in de eerste tijden na het sterfgeval door ziekten worden geplaagd, en zoo ja, of er dan een goeroe in de buurt is, handig genoeg om zich de omstandigheden ten nutte te maken.

Bevalt eene Batak-vrouw van een dood kind, dan wel sterft een zuigeling vóór het tanden krijgen, dan wordt het lijkje meestal des nachts en steeds onder de woning der ouders begraven: eene gewoonte die oorspronkelijk wel haren grond zal hebben gevonden in de vrees voor het stelen der lijkjes, waarvan de bestanddeelen voor het bereiden van toovermiddelen bizondere waarde hebben.

Voelen nu in den eerstvolgenden tijd na de begrafenis de ouders of bloedverwanten van het kindje zich ernstig ongesteld, dan wordt de hulp eener vrouwelijke goeroe ingeroepen, die men onder aanbieding van sirih vraagt aan welke oorzaak de ziekte is toe te schrijven.

Veelal laat zich dan in de keel van de goeroe een geheimzinnig gefluit hooren, waarop zij verklaart dat de ziekte geweten moet worden aan de bégoe van het gestorven kind, welke bégoe tevreden dient gesteld te worden en anders verder onheil over de familie zal brengen.

Door haar werkdadig optreden is die bégoe nu zeer in de achting van de beangstigde verwanten gerezen, en heeft zich het recht verworven voortaan als bitjara goeroe te worden vereerd.

Daartoe is het in de eerste plaats noodig voor de ontevreden ziel eene passende woonplaats in gereedheid te brengen.

In de nabijheid der woning, meest op eenigen afstand daarvóór, wordt eene plek gronds schoon gemaakt, waarna enkele opgegraven beenderen van het lijkje of ook wel eenvoudig eenige aarde van het oorspronkelijke graf derwaarts worden overgebracht. Het nieuwe grafje wordt beplant met pisangs en met siergewassen en veelal met eene bamboezen pagger omringd, terwijl er een offer wordt gebracht van een ei, fijngestampte rijst, boemboeën. Daarmeê is de ingan (plaats) bitjara goeroe gereed.

Aan de goeroe worden als belooning eene kip, eene tikar en pisangs vereerd, soms ook wel een dollar.

Van dien dag af is de bitjara goeroe, de ziel van het kind, tot beschermgeest geworden, en wordt nu geacht verder de familie in hare nooden bij te staan. 
Intusschen is de behandeling die de bitjara goeroe ondervindt geheel af hankelijk van de diensten die zij bewijst.

Gedraagt zij zich goed, dat is te zeggen, gaat het de familie naar den vleesche, dan weet deze dankbaar te zijn, de ingan bitjara goeroe wordt onderhouden, en bij het nuttigen van lekkernijen zonderen de bloedverwanten nu en dan wat voor den beschermgeest af, en leggen dat op zij (tjibal tjibalan) welke stukjes, na afloop van het maal worden weggegooid

Heeft de familie bizondere redenen tot tevredenheid en ziet zịj haren welstand vermeerderen, dan gaat men verder en wordt er eens in het jaar ter eere van den bitjara goeroe een min of meer schitterend feest gegeven. Op den bepaalden dag verzamelen zich al de bloedverwanten en openen het feest met in processie naar de rivier te gaan en daar met het sap van limau's en van gewijde kruiden hunne haren te wasschen (erpangger pangger), eene plechtigheid, die bij de meeste. Bataksche feesten op het programma staat. Vervolgens nemen allen deel aan een gemeenschappelijken maaltijd. Maar het glanspunt van het feest is het zingen der vrouwelijke goeroe, in wier lichaam de bitjara goeroe bij deze gelegenheid geacht wordt te varen. Het is dan ook niet de goeroe die zingt, het is de geest des afgestorvenen die door haren mond zijne klachten en wenschen uit, en dat dikwijls in zoo aandoenlijke tonen dat de toehoorders, vooral die van het zwakke geslacht, zich door hunne gevoelens overmeesterd zien en in een erbarmelijk gesnik en gehuil losbarsten.

De bitjara goeroe trekt het meeste voordeel van die gevoelvolle uitingen zijner bloedverwanten om met verschillende ve:zoeken voor den dag te komen, van wier inwilliging natuurlijk slechts de goeroe eenig voordeel heeft.

Soms ook vraagt de beschermgeest om kain (kleedjes), die dan gedurende de verdere séance door de goeroe worden gedragen, en na afloop vau het feest tot een volgend jaar ter zijde worden gelegd. Blijkt daarentegen de bitjara goeroe lui en nutteloos, en loopt liet de familie tegen, dan wordt er verder geen notitie van haar genomen en laat men hare woonplaats meer en meer vervallen, uitgezonderd wanneer bij eenig nieuw ziektegeval de goeroe die ongesteldheid op rekening van den gekrenkten beschermgeest stelt, wat dan eene verzoening met den bitjara goeroe noodig maakt.

in Naast dezen bitjara goeroe zijn de matei sadawari de machtigste beschermgeesten. Onder matei sadawari verstaat men de geesten van hen die in één dag, en dus een plotselingen dood, zijn gestorven. 
Is iemand in den krijg gesneuveld, is hij vermoord, is hij een tijger ten prooi geworden of heeft hij zichzelf om het leven gebracht, zoo heeft zijn geest kans als matei sadawari te worden vereerd. Maar het is een absoluut vereischte dat de dood een plotselinge zij en voor de ziei van iemand die bijvoorbeeld, na in een gevecht verwond te zijn, eenige dagen later aan zijne wonden bezwijkt, is alle uitzicht ontnomen op een meer verheven rang dan die van gewone bégoe.

Van de matei sadawari kan over het algemeen hetzelfde worden gezegd als van de bitjara goeroe. Ook zij worden zelden of nooit vereerd, wanneer niet eenigen tijd na hunnen dood de gezondheidstoestand hunner bloedverwanten te wenschen overlaat. Hun ingan wordt op dezelfde wijze in orde gebracht als die der bitjara goeroe, en hunne vereering is van dezelfde voorwaarden af hankelijk en heeft op dezelfde wijze plaats.

Beide soorten van geesten eten geen varkensvleesch, dat hun dus ook niet als offer kan worden aangeboden.

Een enkele persoon wist mij te vertellen dat deze beide categoriën van geesten volgens de Bataksche begrippen direkt in den hemel bij Batara Goeroe worden opgenomen, doch ten eerste is dit verhaal blijkbaar in strijd met het bovenstaande en ten tweede was de verteller, hoewel van zeer nabij met de Bataks bekend, een Maleier. Ik geloof dan ook zeer stellig niet dat dit bericht een beeld geeft van de algemeene opvatting der Karo-Bataks, die integendeel van een hemel in den geest van den christelijken geenerlei voorstelling hebben en wier begrippen van een leven hier namaals steeds met deze aarde blijven verbonden. Intusschen is het niet onmogelijk dat onder den invloed van den Islam hier en daar eenige verwarde denkbeelden ingang hebben gevonden omtrent een toekomstig leven in een daartoe bestemd paradijs.

Bij de bitjara goeroe en de matei sadawari sluiten zich aan de toengkoeb. Dit zijn de geesten van vrouwen die gedurende geheel haar leven haren maagdelijken staat wisten te bewaren, een heldenfeit waaraan inderdaad voor eene in geslachtelijke vrijheid opgewassen Bataksche jonkvrouw heel wat verbonden is. Het kan dan ook geene verwondering baren dat de ingan toengkoeb slechts weinige zijn. Ook deze heilige plaatsen worden met siergewassen beplant, terwijl er nu en dan offers worden gebracht, en de toengkoeb beschouwd worden als volkomen bij machte hare achtergelaten betrekkingen een aangenaam en voorspoedig bestaan te verzekeren. Over het 
algemeen komt het mij voor dat de toengkooeb, wasrschịnlijk als groote zeldzaamheden, langer en algemeener in asndenkon blijren dan de bitjara goeroe en matei sadawari, die bijns altịjd na den dood hunner nasste bloedverwanten verwaarloosd worden en spoedig geheel vergeten zijn.

Een ingan toengkoeb vindt men o. a. nabij de kampoeng Tiga Lingga in het Delische landschap Sepoeloeh doewa kota.

De ingan bitjara goeroe van hoofden zijn dikwijls nabij do badplaats der koeta gelegen.

Gaan de bewoners van het dorp ten oorlog, dan versieren zij zich met daar geplukte bloemen en bladeren, die, naar zij meenen, hen tegen vijandelijke kogels zullen beschermen.

De bitjara goeroe, matei sadawari en toengkoeb hebben dit ge= meen, en hierin ligt tevens hun voornaamste onderscheid van de gewone bégoe, dat zij veelal de menschen, speciaal hunne bloed= verwanten welgezind zijn, en op hun lot een gunstigen invoed plegen uit te oefenen, terwijl daarentegen de aanraking met andere geesten, afgezien van de vooral door vrouwen dikwijls zeer gewaardeerde weemoedige vreugde verbonden aan het houden van communicatie met dierbare afgestorvenen, den menschen niet dan schade en last veroorzaakt.

Alle zielen van afgestorvenen, die niet onder de drie reeds behandelde categoriën vallen, verkeeren in den staat van bégoe. Deze bégoe zwerven, onzichtbaar voor het menschelijk oog, overal op de aarde rond. Daarbij blijft de schuld der boozen op hen rusten, zonder echter naar het schijnt op eenige andere wijze aan hen bezocht te worden dan doordat zij meer moeten reizen en trekken, terwijl de braven een wat kalmer bestaan voeren en veelal ergens in het bosch of op de bergen een vast verblijf hebben (kramat). Zoo wonen op den Goenoeng Sibajak de zielen der beide zusters Siberoe Tandang Maria en Siberoe Tandang Karo, dochters van den penawar (groote goeroe) Kandebata, die beide aan de pokken bezweken, en met haar de geesten van alle andere menschen die aan die ziekte ten offer vielen.

Alle bégoes kunnen om voedsel vragen, wat zij uitsluitend doen, door hem of haar tot wien zij hun verzoek willen richten eene ziekte op het lijf te jagen. Wien zij daarbij krijgen is hun tamelijk onverschillig. Hoewel minder absoluut dan de bitjara goeroe enz., geven zij de voorkeur aan hunne bloedverwanten, doch wanneer zij erg hongerig zijn, grijpen zij aan wie hen tegenkomt, 
Beleedigingen, bijvoorbeeld het kappen van hout op plaatsen waar zij hun gewoon verblijf hebben, vergeven zij evenmin als de straks te behandelen hantoe, maar bezoeken den overtreder met kwalen tot hij hen door een groot offer weet te verzoenen.

Dr Hagen deelt in zijn meergenoemd geschritt ook omtrent de bégoe's een en ander mede, doch beschouwt hen blijkbaar als een soort kobolden, bosch- en berggeesten, geenszins als de zielen van afgestorvenen. Misschien, hoewel niet erg waarschijnlijk, wijken in dit opzicht de begrippen van Toba- en Timor-Bataks van die der Karo's af. E'en overtuigend bewijs dat deze laatsten in de bégoe's werkelijk de zielen hunner dooden zien, vindt men in het feit dat in de zoogenaamde moesoeh berengi telkens weêr de bégoe van een vermoorde om recht vraagt, of met wraak, met moord en brandstichting dreigt. Zooals bekend is, verstaat men onder moesoeh berengi (woordelijk vertaald: nachtelijke vijanden) of poelas, de op bamboe geschreven brieven, die door zich verongelijkt achtende Bataks in of nabij de kampongs hunner tegenstanders en tegenwoordig helaas! ook dikwijls op de plantages der Europeesche ondernemers worden opgehangen, en waarin zij gewoonlijk onder bedreigingen op wegneming hunner grieven aandringen. Geldt het nu eene zaak waarin een sedert overleden persoon oorspronkelijk partij was, zoo noemt de opsteller van den brief, meest een bloedverwant van den doode, zelden zijn eigen naam, maar laat het voorkomen alsof de poelas door den bégoe van den doode was geschreven. Zoo werd nog voor weinige maanden nabij eene koeta van het landschap Serbanjaman de volgende brandbrief opgehangen gevonden.

"Eindah soerat koe tjanggoeng nina bégoena Si Tkoet kataken "di laäng ioelihkenna Si Iantak djelmankoe doewa di laäng ioelih "kenna koe soeloeh koe boenoeh djelına nina bégoena Si Ikoet."

Dit beteekent, zooveel mogelijk woordelijk vertaald:

“Dezen brief hang ik op, zegt de bégoe van Si Ikoet, om te "zeggen dat, wanneer Si Lankat niet terug doet keeren mijne twee "menschen (bijv. Si Ikoets vrouw en kind), wanneer hij die niet "terug doet keeren, dan sticht ik brand en dood ik menschen, zegt "de bégoe van $\mathrm{Si}$ Ikoet."

Intusschen schijnt toch in enkele bizondere gevallen het gronddenkbeeld dat een bégoe de geest van een afgestorvene is bij de KaroBataks verloren te zijn gegaan. Zoo weten zij veel te vertellen van den bégoe Sidangbeila, ook bégoe Menggep of bégoe Lagaloemajang genoemd, die in de kampongs woont, liefst in nieuwe huizen, en 
daar nu eens in de deur, dan weer in het huis of op het dak, ook wel aan de bron verblijf houdt.

Behalve in het ziek maken en doen sterven der bewoners, waarbij hij het vooral op kraamvrouwen voorzien heeft, munt deze bégoe nog vooral uit in het verstoren van den huiselijken vrede.

Het is de vrees voor dezen kwaadaardigen geest die den KaroBatak verhindert een nieuw huis te betrekken alvorens het door den goeroe te hebben laten onttooveren. Daartoe wordt door den wijzen man zeker toovermiddel bereid, toepoeng tawar genoemd. Schoteltjes met dit mengsel worden aan de beide deuren op een soort bamboezen standaardjes geplaatst. Elk die de woning betreedt, doopt een vinger in de toepoeng tawar en bestipt zich daarmede voorhoofd, wangen en borst.

Bij de vereering van dezen bégoe Sidangheila, die om zoo te zeggen in elke kampong zijne kunsten verkoopt, en omtrent wiens komst niemand eenige kennis schijnt te hebben, is blijkbaar elke gedachte aan de ziel van een afgestorvene lang verloren gegaan. Intusschen is het niet onmogelijk dat het geloof aan dezen plaaggeest door de Karo's van een anderen Batakstam is overgenomen. Alle bégoes, die inderdaàd als de geesten van afgestorvenen worden beschouwd, kunnen door de goeroes worden opgeroepen en door tusschenkomst dezer mediums hunne wenschen kenbaar maken of hurne groeten aan hunne nog onder de levenden wandelende betrekkingen overbrengen. Dit geschiedt echter slechts incidenteel, eene ingan als die der bitjara goeroe enz. wordt niet voor hen in orde gemaakt, en van eene geregelde vereering is geen sprake.

Eene uitzondering op dien regel wordt echter dikwijls gemaakt voor de bégoe's van groote hoofden en beroemde goeroes. Op hunne graven wordt algemeen geofferd en hun goede wil wordt geacht van groot nut te zijn. Zelfs de Maleische paardenhandelaars die de hoogvlakten bezoeken offeren op de graven der sibajaks van Kaban Djahe en Baroe Djahe, eerst, bij den aanvang hunner reis, slechts sirih, later wanneer alles goed is afgeloopen, eene geit of witte kip.

In bijna alle eenigszins aanzienlijke koetas vindt men doodenhuisjes (griten) waarin het dorpshoofd de beenderen of ten minste de schedels zijner voorvaderen bewaart. Bij de oprichting dezer griten verzuimt men nimmer de bégoe's op te roepen van de laatst gestorvenen onder hen, wier gebeente hier zijjn laatste rustplaats zal vinden. Verder wordt er echter meestal weinig notitie van genoinen.

De Karo-Bataks vereeren hunne voorouders nimmer in de gedaante 
van steenen beelden, maar dat gebruik schijnt volgens dr. Hagen bij de Toba-Bataks algemeen te bestaan.

Toch waag ik het hier de juistheid dezer laatste mededeeling eenigszins in twijfel te trekken. Dr. Hagen toch zegt o. a.: "Diese steinernen Ahnenbilder heiszen pengoeloebalang."

Aan het woord pengoeloebalang hecht niet alleen de Karo-, maar ook de Toba-Batak, zooals wij in het vervolg zien zullen, eene geheel andere beteekenis. Het is weliswaar een steenen beeld, maar de kracht die er in schuilt ontleeent het uitsluitend aan de tooverbrij hier en daar er in aangebracht, en die tooverbrij heeft met de voorvaderen van hem, voor wien de pengoeloebalang wordt vervaardigd, hoegenaamd niets uit te staan.

Het is hier de plaats om een enkel woord te wijden aan een onderwerp, waarvan de behandeling eigenaardige moeilijkheden oplevert, en dat vooral omdat het hier een Bataksch geloof of bijgeloof geldt, waarvan onder Europeanen ook geen enkel spoor wordt aangetroffen en dat aan hun geestesleven ten eenenmale vreemd is. Ik bedoel het geloof aan de tendi (in het Tobasch dialect tondi), een Bataksch woord dat niet met juistheid te vertalen is, waarvan de beteekenis .ligt tusschen onze begrippen: ziel en geleidegeest.

Het woord ziel op zich zelf kan het Bataksche begrip niet met voldoende juistheid weergeven. Ten eerste beschouwen wij de ziel als haar verblijf houdende in het menschelijk lichaam, de tendi houdt zich daarbuiten op en van de plaats die zij naast, voor, achter, boven of beneden ons inneemt, hangt voor een groot deel onze welstand af. Verder hangt volgens Westersche begrippen de ziel allernauwst samen met het leven en het bewustzijn; men zegt bijv. een zielloos lichaam, wat dan beteekent een levenloos lichaam. Een Batak daarentegen kan zeer goed zijn tendi verliezen zonder daarom direct te sterven of zelfs krankzinnig te worden, al blijft dat verlies, vooral op den duur, toch eene ernstige en gevaarlijke zaak.

Wanneer een Batak hevig schrikt van een tijger of eene slang, of hij bij het oversteken eener rivier bijna verdrinkt en daardoor in grooten angst geraakt, pleegt zijne tendi er van door te gaan. De gevolgen blijven niet uit, de man wordt ziek en slechts de goeroe kan raad schaffen. Is deze knap in zijn vak, dan heeft hij de oorzaak der ongesteldheid spoedig ontdekt. De tendi is op den loop, en gelukt het niet haar terug te lokken, dan ziet het er voor den patient slecht uit. Men neemt daarom een gantang beras, een ei, eene ikan senangin, enz. en doet die in eene pernakan (gevlochten 
rijstzakje). Dit plaatst men weêr in eene soempit (een dergelijk maar grooter zakje) samen met een zilveren kalkdoosje, een armband, een mes, enz. De soempit wordt toegebonden en bovenop legt men bladeren van elf bepaalde planten, alsmede merg van een pinang. Twee personen houden de soempit boven den zieke vast, terwijl de goeroe in een plechtig gezang de tendi verzoekt terug te komen. Geeft deze aan het verzoek gehoor, dan is dit kenbaar door een hevig trillen van de soempit. Komt daarentegen de tendi niet terug, dan volgt de dood van den lijder.

Op de vraag of het al dan niet de tendi is die na den dood van eenig persoon bégoe wordt, wist geen enkele Batak mij met volkomen zekerheid te antwoorden. De meesten meenden dat zulks wel het geval zou zijn.

Volgens dr. Hagen zouden de Bataks gelooven in het bezit te zijn van drie tendis. Ook deze bewering moet uitsluitend berusten op de mededeelingen van Toba- en Timor-Bataks. Bij mijne onderzoekingen vond ik geen enkelen Karo die op meer dan ééne tendi aanspraak makte.

Toch is er iets dat hier licht tot verwarring aanleiding zou kunnen geven.

Elke Karo-Batak namelijk gaat door het leven vergezeld door twee onzichtbare beschermgeesten, die hij in gewone omstandigheden vrij wel verwaarloost en negeert, maar die hij in groote gevaren te hulp roept. Het zijn zijn kaka en zijn agi. Daaronder verstaat hij respectievelijk het vocht, waarvan de uitvloeiing zijne geboorte voorafging en de nageboorte (poesat samadaura) die de bevalling besloot. Van die beide broertjes meent hij in geval van nood krachtige ondersteuning te wachten te hebben en roept hen dan aan in de formule: "Mari kam kakankoe aginkoe si ras akoe toeboeh doebei "kakankoe erkoeta i poentja papan agin koe erkoeta teroeh karang;" dat beteekent: "komt hier, mijn "oudere en mijn jongere broer, die samen met mij zijt geworden, "mijn oudere broer die woont op het uiteinde van de plank" (met deze plank wordt de zoogenaamde anak laoe bedoeld die in de Bataksche huizen van de eene deur naar de andere loopt en als een soort gootsteen dient) "mijn jongere broer die woont onder "het huis" (waar de nageboorte begraven wordt).

Het zal niemand verwonderen dat de Batak er den hoogsten prijs op stelt met zijne tendi die, hoewel het beste deel van zijn ik uitmakende, geheel onafhankelijk is van wat wij den wil noemen, op een goeden voet te blijven. 
Gelukkig bestaat daartoe een eenvoudig en krachtig werkend middel, namelijk het zich aanschaffen van eene oepah tendi. Om te weten te komen waaruit die oepah tendi voor elk bizonder individu dient te bestaan, wordt weder de hulp van een goeroe ingeroepen. Soms doet deze de wetenschap op uit de lijnen in de hand van den vrager, soms beveelt hij het erpangger (wasschen der haren) aan en trekt dan zijne conclusie uit het vallen der gebruikte limau, soms ook gaat hij op nog andere wijze te werk. Als resultaat zijner onderzoekingen deelt hij na langer of korter tijd aan zijn client mede welk voorwerp door diens tendi wordt verlangd. Die voorwerpen zijn van den meest verschillenden aard. Een mes, eene gong, een kleedje, een karbouw, enz. enz. worden dikwijls bij monde van den goeroe door den tendi geëischt. De betrokken persoon rust dan niet voor hij genoeg dollars heeft verzameld om de begeerige ziel tevreden te stellen. Het voorwerp wordt gekocht en zorgvuldig bewaard, terwijl de eigenaar zich hoogst gelukkig gevoelt in het bewustzijn dat zijne tendi, vol gehechtheid aan de hem ten geschenke gegeven oepah, nu aan elke verleiding om op den loop te gaan weerstand zal weten te bieden. Voor sommige personen is de oepah tendi van anderen aard, en bestaat uit eene kleine aanplanting van pisangs, sierplanten, enz. enz.; uiterlijk geheel overeenkomende met de ingan bitjara goeroe, en evenals deze min of meer goed onderhouden naarmate van den voor- of tegenspoed die den betrokken persoon ten deel valt. Vooral aan lieden die op het punt staan te trouwen wordt het aanleggen van zulk een tuintje door den goeroe nog al eens als een lievelingswensch der tendi opgegeven.

Wij kunnen hiermeê de zielen der afgestorvenen voorloopig met rust laten om er straks bij de behandeling der pengoeloebalangs, enz. nog eens op terug te komen, en onze aandacht wijden aan de beschouwing van wezens, wier natuur veel vager en veel geheimzinmiger is dan die door den dood van vleeschelijke menschen ontstane bégoe's.

Wie en wat eigenlijk de hantoe's zijn, wist geen Batak mij te verklaren. Slechts een enkele goeroe kwam na lang aarzelen voor den dag met de meening dat zij wel gestorven bégoe’s konden wezen. Wel zoo waarschijnlijk dunkt mij de onderstelling dat men hier met bepaalde natuurgeesten te doen heeft, met de vertegenwoordigers van bergen en wouden, van beken en stroomen. Zeker is het dat de hantoes de bewoonde streken en de nabijheid der menschen vermijden en zich uitsluitend in de wildernis ophouden. Zoo lang men hen ongemoeid laat en hun terrein eerbiedigt, zijn zij on- 
gevaarlijk. Wee echter den overmoedige die het waagt hen in hunne schuilplaatsen te storen. Hun wraak is niet minder snel dan die der bégoe's, hoewel van eenigszins anderen aard. Want terwijl de laatste inwendige ziekten teweegbrengen, zijn hantoes er op uit hunne slachtoffers te misvormen, terwijl zij zich bij minder ernstige beleedigingen ook wel wreken door het veroorzaken van slechte droomen, waarvoor de Bataks eene groote vrees koesteren.

Hoewe] zij gewoonlijk onzichtbaar zijn, staat het toch in hunne macht zich desverkiezende aan het menschelijk oog te vertoonen, en hebben dan ook enkele goeroes, meest vrouwen, het genoegen gesmaakt hen te aanschouwen.

Zoo is men tot de wetenschap geraakt dat onder de hantoes niet alleen beide geslachten zijn vertegenwoordigd, maar ook diergestalten niet zeldzaam zijn. De menschelijk gevormde hantoes zijn meest gekleed in wit of rood.

Eene geliefde verblijfplaats dezer geesten is de berg Sampoeran Poetih bij Besoekoem, waar zij samen leven met de aanstonds te behandelen omangs. Een Batak, die daar bosch had gekapt en gebrand, zag zijn nek 90 graden omgedraaid; een ander kon zijn mond niet meer openen tot hij een geit als zoenoffer had gegeven.

De hantoes van den Sampoeran Poetih zijn van reusachtige gestalte en rijk aan karbouwen. De mannen dragen lange, witte baarden. Weldaden worden door de hantoes nimmer aan de menschen bewezen.

Van Sombaons en Soemangots, waarvan dr. Hagen uitvoerig verhaalt, heb in de Karo-landen nooit hooren spreken, en op mijne navraag daaromtrent nimmer eenig uitsluitsel gekregen. Daarentegen is het woord soemangot wel bekend bij vele Maleiers in Deli en Serdang, die er eene beteekenis aan hechten min of meer overeenkomende met die van het Bataksche tendi.

Algemeen is onder de Karo-Bataks het geloof aan de omang, die door dr. Hagen ten onrechte verward worden met de orang boenian.

De omang komen tamelijk wel overeen met onze middeneeuwsche Kaboutermannetjes. Het zijn dwergen die huwen en zich voortplanten en meest bij of op de bergen wonen Hunne gestalte wijkt in zoover van die der menschen af dat zij hunne roeten verkeerd dragen. Hun karakter vertoont eene sterke mengeling van goed en kwaad. Zij zien niet gaarne dat men, hun gebied betredende, verzuimt een behoorlijk offer te brengen. Wie bijvoorbeeld den goenoeng Sibajak beklimt, doet wel eene witte kip te offeren, anders kan hij er zeker van zijn 
dat de daar zeer talrijke omangs hem van boven af met steenen zullen bombardeeren.

De Bataks, die voor den eersten keer op eene reis van of naar het plateau de passen doortrekken, plegen, op het hoogst punt gekomen, een weinig sirih te kauwen samen met wat aarde of een opgeraapt blad en zich met die brij het gelaat te besmeeren. Evenmin als dr. Hagen vermocht ik er achter te komen wat deze ceremonie eigentlijk te beduiden heeft.

De omang zijn zeer diefachtig en ontvoeren gaarre menschen, waarbij de mannelijke omang het vooral op aardige meisjes en de vrouwelijke het meer op knappe jongens hebben voorzien. De zoo geschaakte personen worden dikwijls jaren lang in gevangenschap gehouden.

Eene eigenaardige illustratie van deze eigenschap der omang geeft de volgende legende.

Perasi, een der voorvaderen van het tegenwoordige hoofd der kampong Penoengkiran in de doesoen van Soekapiring, had eene beeldschoone dochter die de begeerte opwekte van den vorst der omangs te Oeroek Bintang Maria. Deze begreep evenwel dat de vader der jonge maagd haar niet zoo licht aan een omang zou afstaan, en hij dus door list zijn doel kon bereiken. Daarom trok hij naar Penoengkiran en sloeg aan het hoofd een bondgenootschap voor.

Perasi zou hem het meisje ten huwelijk geven, maar daarentegen zou de omangvorst niets meer of minder bewerken dan dat de sultan van Deli Perasi als zijn heer en meester zou erkennen, waartoe hij de Soengei Deli in de Soengei Seroewai zou leiden, en niet in hare oude bedding terug zou laten keeren vóór de Sultan zich aan Perasi had onderworpen. Mocht de Sultan boos worden en met een leger naar boven trekken, dan zouden alle giftige dieren en giftige planten op dat leger worden losgelaten.

Eene zevendaagsche duisternis, gedurende welke de omangvorst zijne toebereidselen zou maken, zou de uitvoering van het contract voorafgaan. Perasi was hoogelijk net dit plan ingenomen en beloofde het meisje aan zijn bondgenoot te zullen afstaan. Terstond viel nu de duisternis in die men met recht eene pikzwarte kon noemen. Toen het nu echter vijf etmalen zoo donker bleef en men geen hand voor de oogen kon zien, werd Perasi bang en nam zijn toevlucht tot geweerschoten en bekkenslag om het licht te doen terugkeeren. Dit gelukte ook, maar helaas te laat. De listige omang had van den langen nacht gebruik gemaakt om de maagd te rooven. 
terwijl hị de Delirivier in hare bedding had gelaten. De jonkvrouw was verdwenen en nooit werd weder iets meer van haar gehoord.

Tot op den huidigen dag durven de meisjes uit het geslacht van Perasi, voor zoover zij er goed uitzien en wat blank zijn, niet meer langs den Oeroek Bintang Maria gaan zonder zich eerst zwart te hebben gemaakt.

De omang wonen gaarne in steenen huizen. Eene zoodanige roemah omang is de uitgeholde rots, waarvan dr. Hagen teekeningen en eene beschrijving geeft en die ook dosr mij werd bezocht. De inlichtingen, aan dr. Hagen omtrent dat gedenkteeken verstrekt, zijn niet geheel juist.

Eene bepaalde nis vindt men daar binnen slechts rechts van den ingang, volgens de Bataks was dat de slaapplaats van den vorst der omangs. Aan den achterwand vindt men ook eene dergelijke uitholling, doch die slechts enkele duimen diep is. Onder het gewelf loopt langs den geheelen binnenkant een soort richel. Aan den ingang zijn uitwendig nog zeer merkbare teekenen van versieringen aan de oppervlakte van het rotsblok vindt men eene ongeveer vier voet hooge menschenfiguur zeer ruw uitgehouwen. Het geheel is zeer merkwaardig, een dier raadselen die ons door lang vervlogen eeuwen worden opgegeven.

Ook aan dezen steen en de omangs, die gezegd worden er eenmaal te hebben gehuisd, is eene legende verbonden.

Lang geleden ging een Batak van het naburige Soerian Tani visschen in de Laoe (Soengei) Petani. Aan de rivier vond hij in twee uithollingen in den oever een gantang beras en een gantang djagoeng,

Hij nam ze meê naar huis, en zie, den volgenden morgen was de rijst goud geworden en de maïs zilver. Toen dacht hij verheugd: als men in dien stroom zulke visschen vangt, zal ik er elken dag maar gaan hengelen. En hij trok er wêer heen. Op de plaats waar hij den vorigen dag zijne vondst had gedaan, ontmoette hij nu een omang. Begrijpende dat hij aan dezen het goud en het zilver had te danken, riep hij ook voor het vervolg zijne gunsten in. De omang antwoordde hem zeer welwillend; hij beloofde voor den Batak eene ladang te zullen aanleggeu nabij het omanghuis, mits de begunstigde er tegen niemand van repte en nooit anders dan alleen de ladang naderde. De Batak beloofde dit en de omang ging aan het werk.

Toen echter de padi rijp was, werd de vrouw van den Batak nieuwsgierig en verlangde de mooie ladang te zien die haar man 
beweerde te bezitten, maar waarvan zij nooit iets had bespeurd. Zij smeekte haren echtgenoot haar eens meê te nemen, maar deze weigerde hardnekkig. $\mathrm{Nu}$ verzon zij eene list en toen haar man weêr naar de ladang wilde gaan, naaide zij zeker poeder in zijne kleederen, welk poeder door eene kleine opening een uitweg kon vinden. Langs het dus verkregen spoor volgde zij haren echtgenoot en bereikte de ladang. De omang echter was verwoed over hare verschijning; hij beschouwde daardoor het contract als verbroken en verliet terstond met zijne geheele familie de ladang en zijne steenen woning om er nimmer weêr te keeren.

Wat de Orang boenian betreft, deze zijn voor hețuiterlijke gewone menschen, die intusschen het vermogen bezitten niet alleen zich zelven, maar ook hunne huizen, hunne ladangs en tuinen onzichtbaar te maken. $\mathrm{Zij}$ wonen meest hoog op de bergen, en er is in de omtrent hen in omloop zijnde verhalen iets waarin men aanleiding zou kunnen vinden tot de veronderstelling dat men hier niet geheel met producten der Bataksche fantasie heeft te doen, maar dat wellicht in de hoogste en minst genaakbare bergstreken enkele rondzwervende Bataks worden of werden aangetroffen, die om de eene of andere misschien zeer geldige reden, hunne stamgenooten zooveel mogelijk vermijdende, zich dientengevolge langzamerhand met een nimbus van geheimzinnigheid omgeven zagen, en zoo aanleiding gaven tot de legende der Orang boenian.

Wat vooral aan deze meening grond geeft, is dat de Bataks, anders zoo geneigd alles te overdrijven, de orang boenian steeds bepaald als menschen voorstellen, en hen, behalve de macht zich onzichtbaar te maken. geenerlei bovennatuurlijke eigenschappen toekennen. Algemeen wordt zelfs door hen beweerd dat de orang boenian vroeger in betrekkelijk talrijke groepen naar de kustplaatsen plachten te trekken om daar zout te koopen.

$\mathrm{Na}$ gesloten handel trokken zị weêr naar boven, doch in het gebergte ging elk spoor van hen verloren. Later verminderde hun getal en in de laatste jaren werden zij op de gewone wegen waarlangs het verkeer tusschen de hoogvlakte en de kustlanden wordt onderhouden, niet meer waargenomen.

Dit verhaal heeft zeker niets buitensporigs. Er is niets onmogelijks of zelfs onwaarschijnlijks in dat nu en dan voortvluchtige misdadigers of door machtige vijanden vervolgde bannelingen in het hooggebergte, dat door hunne stamgenooten uit vrees voor begoes, hantoes en omangs slechts noode betreden werd, en waar 
zij, mits zich zooveel mogelijk verborgen houdende eene betrekkelijk volkomen veiligheid genoten, eene schuilplaats zochten, welke zij nog zekerder wisten te maken door nu eens hier dan eens daar hunne ladangs aan te leggen.

Geheel buiten aanraking met het verdere menschdom konden zij echter niet blijven; enkele malen moesten zij naar beneden voor den inkoop van zout en andere benoodigdheden. Eene enkele maal werden hunne woningen of velden ontdekt door een verdwaalden zoeker van rotan of zwavel die later of de plaats niet meer kon terugvinden óf haar, verlaten en weêr in bosch herschapen vond, en dan, in zijne kampong teruggekeerd, geheimzinuige verhalen opdischte.

' $t$ Is niets dan eene hypothese, maar die, dunkt mij, de legende der orang boenian op eenvoudige wijze verklaart. ${ }^{1}$

Hiermede kunnen wij de behandeling besluiten der bovennatuurlijke wezens, aan welke het volksgeloof der Karo-Bataks een persoonlijk en zelfstandig bestaan toekent, en die hij beschouwt als de bewerkers van een deel van zịn voorspoed en van al zijne rampen.

Wanneer zwaar leed hem treft of een kleine tegenspoed hem overkomt, steeds is de een of andere bégoe of hantoe daarvan de bewerker, en is de verzoening van dien geest zijn eerste zorg. Gelukkig dat zij in den aard humner eischen heel wat bescheidener zijn dan in het aantal, en het offer van eene kip, in zeer enkele gevallen van eene geit, al het kostbaarste is, wat zij vorderen. Gewoonlijk komt het slachtoffer er af met wat rijst, dikwijls tot meel gestampt, wat sirih, pisang, bloemen en vooral wat boemboeën, der geesten lievelingsspijs.

Schijnbaar vereert de Batak behalve dit geestenheir nog tal van stoffelijke voorwerpen; steenen menschenfiguren (pengoeloebalang), tooverstokken (tonggal penaloean, tongkat malêhat, perong djalan), pagar en amuletten van verschillenden aard (perminakan, pendapattan). Maar dringen wij door tot op den grond dier vereering, dan stuiten wij overal op de bégoe's, de zielen der afgestorvenen. In het algemeen toch kan men zeggen dat met uitzondering der

1 In het Woordenb. van v. d. Tuuk leest men s. v. boeni $=$ verborgen, bewaard) coerang boenijan, Men. Mal., zekere onzichtbare geesten, die den mensch meestal begunstigen (Mandailingsch dialect) Volgens van Hasselt (Midden Sumatra Dl. III blz. 78) zijn bij de Menangkabausche Maleiers de boenian de geesten der mijnen. Hiermede stemt de mededeeling van v. d. Toorn overeen (Bijdragen Vde Reeks DI. V blz. 100). 
boven besproken oepah tendi en van sommige amuletten (pendapattan), geen van de fetischen der Karo-Bataks eenige macht bezit uit zich zelve, maar*alle geacht moeten worden die slechts gekregen te hebben door de gedeeltelijke vulling met eene tooverbrij (poepoek) waarvan zekere deelen van het menschelijk lichaam, de oogen, de lippen, de neus, de geslachtsdeelen, enz. de voornaamste bestanddeelen zijn. Met die deelen wordt de begoe van hun voormaligen eigenaar beschouwd in de pengoeloebalang, of in den tooverstok te zijn gevaren.

Pengoeloebalang's worden in de Karolanden zoowel op het plateau als in de Doesoen nog overal angetroffen, in de Doesoen echter uitsluitend bij oude kampongs. Ze zijn ruw uit steen gehouwen en vertoonen soms een menschenfiguur, meest echter slechts een hoofd. Het ondereinde loopt min of meer spits uit, zoodat het in den grond kan worden gestoken. Plaat III behoorende bij dr. Hagen's meergenoemd geschrift geeft van verschillende dezer kunstelooze beelden eene duidelijke voorstelling.

Pengoeloebalang's kunnen slechts door de goeroes worden vervaardigd. Van oudsher schijnen inzonderheid de Timor- en Toba-Bataks in dit deel van het toovenaarsvak te hebben uitgemunt. Daarentegen leggen de goeroes der Karo-Bataks zich zelden op deze industrie toe, waarschijnlijk vooral omdat de zeden van dezen stam steeds zachter en menschelijker waren dan die zijner Oostelijke en Zuidelijke buren, en het verkrijgen van de lijken voor de vervaardiging der beelden benoodigd, daardoor met vele bezwaren gepaard gaat.

En toch is zulk een lijk een absoluut vereischte voor het samenstellen van de tooverbrij die het eenige werkzame bestanddeel van de pengoeloebalang uitmaakt en hier of daar in eene kleine daartoe geboorde en min of meer verborgen holte in het beeld wordt aangebracht. Soms ook bepaalt men zich er wel toe de pengoeloebalang met de poepoek et bestrijken.

Eenvoudige lijkendiefstal kan over het algemeen aan het door de goeroes beoogde doel niet beantwoorden, daar slechts de lichamen van bitjara goeroe, matei sadawari en voor het samenstellen van andere fetischen ook wel van in het kraambed gestorven vrouwen eene geschikte grondstof voor hunne preparatiën opleveren.

De lijken van in den strijd gevallen vijanden leveren nog het best bereikbaar materiaal, maar ook deze komen niet dagelijks voor, de overblijfselen van zuigelingen en kraamvrouwen worden door de achtergebleven betrekkingen steeds heimelijk en op veilige plaatsen 
ter aarde besteld, zoodat zij voor de aanslagen der goeroes zooveel mogelijk beveiligd zijn. Geen wonder dus dat deze er wel eens toe overgaan zich door een heimelijken moord het lichaam van een matei sadawari te verschaffen. Nog voor enkele jaren werd in de Soengei Seroewai nabij de kampong Teromboe een lijk gevonden ontdaan van al die deelen die voor den Batakschen toovenaar van waarde zijn. De algemeene opinie wees dan ook een in de nabijheid wonenden goeroe als moordenaar aan, doch daar de zaak eerst na geruimen tijd ter oore van de justitie kwam, leverde een gehouden onderzoek geenerlei resultaten op. Ook bij een te Namoe Bahara gepleegden moord werd het lijk van het slachtoffer op dergelijke wijze verminkt gevonden (1890). Bij beide misdaden bestonden waarschijnlijk andere hoofddrijfveren, doch de daders trokken tevens partij van de gelegenheid om de materialen voor het vervaardigen der zoo gewaardeerde toovermiddelen te verkrijgen.

Men onderscheidt verschillende soorten van poepoek, als: poepoek toelbas, poepoek perminakan, poepoek penergang. Bij de bereiding der laatste komen geene lijken in het spel, doch heeft men vooral de versche asch en splinters noodig van een door den bliksem getroffen boom.

Bij de Doesoenbevolking zijn de pengoeloebalang's gedurende de laatste jaren met rassche schreden in aanzien gedaald, een natuurlijk gevolg van de toeneming van onzen invloed en van de daarmeê gepaard gaande vermeerdering der veiligheid. Een pengoeloebalang toch dient in de eerste en voornaamste plaats als waarschuwing tegen oorlogsgevaar. Dreigt van buiten een nijdige vijand met krijg en overval, dan is het de plicht van een pengoeloebalang daarvan door nachtelijk geschreeuw, door slaan op eene gong, door kloppen op de karebangan (deur van de pagger die de kota omgeeft), enz. mededeeling te doen.

Verder zijn zij eigenlijk nergens goed voor, hoewel hun hier en daar in sommige gevallen offers worden gebracht, bijvoorbeeld wanneer de te veld staande oogst veel van de muizen te lijden heeft of de klappers door kevers worden opgevreten.

Voor eene kota, die niets van vijanden te vreezen heeft, bestaat dan ook weinig behoefte aan een pengoeloebalang, en zoo worden deze beelden tegenwoordig in de Doesoen bijna overal verwaarloosd, terwijl hun in de onaf hankelijke landen nog veel eer wordt bewezen.

Zij bevinden zich meest op eenigen afstand van het dorp in een boschje van sierplanten. Eens in het jaar of om de twee jaren wordt hun te eten gegeven en wel een roode hond of eene roode kip. Ook $5^{\text {e }}$ Volgr. VII. 
in het geval van dreigenden oorlog brengt men hun offers om hen tot grootere oplettendheid te bewegen.

Uit het bovenstaande blijkt dat de Karo-Bataks in de pengoeloebalang's geenszius de vertegenwoordigers zien van de geesten hunner voorvaderen, maar uitsluitend de omhulsels van de poepoek, welke poepoek den geest of een deel van den geest bevat of gebonden houdt van dien enkelen afgestorvene, wiens lijk bij de vervaardiging der brij eene rol heeft gespeeld. (Deze opvatting is ook die van dr. G. A. Wilken; zie Het animisme bij de volken van den Indischen archipel, bladz. 172, noot).

"Den geest of een deel van den geest", zeg ik.

Het verdient namelijk opgemerkt te worden dat met de uit één lijk vervaardigde poepoek aan tal van pengoeloebalangs, tongkat malaekat, ${ }^{1}$ pagar perminakan, enz. tooverkracht kan worden verleend. Of dit komt doordat de goeroes in het belang hunner broodwinning zoo nauw niet zien en dus deze kwestie steeds onaangeroerd hebben gelaten, of wel doordien de bégoe van den doode wordt beschouwd niet in een der voorwerpen zijn intrek te hebben genowen, maar de verspreide overblijfselen van zijn lichaam om beurten te bezoeken, ziedaar eene vraag waarop ik geen antwoord durf geven.

Een dorp heeft dikwijls twee of meer dezer steenen figuren, die worden beschouwd als gemeenschappelijk eigendom van de koetabewoners, of ook wel van een deel daarvan, wanneer het dorp bijv. door meerdere naast elkaâr staande hoofden wordt bestuurd.

Veelvuldig komt het vó́r dat een pengoeloebalang na den dood van den goeroe die haar vervaardigde wordt verwaarloosd en dat uit vrees. Wanneer namelijk hij, die tusschen de dorpsbevolking en den schutsgeest als middelaar optrad, niet meer onder de levenden is, waagt niemand het meer de verblijfplaats van den pengoeloebalang te betreden. Ik deed er persoonlijk de ondervinding van op.

Op zekeren middag bracht ik van uit de kampong Namoe Rambei een bezoek aan de pengoeloebalang van het nabijgelegen Goenoeng Berita. Deze pengoeloebalang werd reeds lang niet meer vereerd, zijn goeroe was gestorven en er had zich geen vervanger opgedaan.

Intusschen stond het boschje dat de vervallen grootheid omgaf, nog altijd in een reuk van heiligheid. Men vreesde zoowel de niet meer vereerde pengoeloebalang als de bégoe van zijn' goeroe, die verondersteld werd hier rond te zwerven. Niemand durfde met mij het

1 In het Tobasch-dialect heet dit voorwerp toekkot malehat. 
boschje binnendringen en de Bataks raadden ook mij af de geesten zoozeer te trotseeren. Ik liet mịj natuurlijk niet weêrhouden, kroop naar binnen en vond na lang zoeken het beeld dat intusschen in verscheidene stukken bleek gebroken. Maar de straf voor mijne vermetelheid bleef niet uit. Ik had namelijk mijn horloge te Namoe Rambei laten liggen, en toen ik daar nu in de djamboer (het vreemdelingenhuis) terugkeerde, vond ik dat het uurwerk gedurende mijne afwezigheid stil was blijven staan, waarschijnlijk doordat een der aanwezigen er aan had gepeuterd. Maar de brave Bataks vatten de zak anders op. Hier was geene menschenhand, neen, hier waren de geesten in het spel geweest. Hen had ik beleedigd, verwaten was ik in hunne schuilplaats doorgedrongen en hun wrekende arm had mij weten te vinden. In mijn horloge hadden zij mij getroffen.

Het afleggen van eeden op de pengoeloebalang's is bij de KaroBataks onbekend.

Aan hetgeen ik reeds mededeelde omtrent de vervaardiging dezer beelden dien ik nog toe te voegen dat het plegen van zoo beestachtige wreedheden als het doodmartelen van jonge knapen, door dr. Hagen vermeld, bij de Karo-goeroes niet schijnt voor te komen. Het zijn overigens ook niet uitsluitend de pengoeloebalang's welke als waarschuwers bij oorlogsgevaar belangrijke diensten kunnen bewijzen.

Zoo vervult voor verscheidene koetas in Soekapiring een heilige rots, de Batoe Pikpik bij Boeloe Auer dezelfde rol. De legende verhaalt daaromtrent dat in vroeger tijd een groote goeroe van de marga Karo karo Kemit, Si Rahani genaamd, nabij de kampong Sajoem zoodanig door een neervallenden boomtak werd getroften, dat deze door zijn nek in zijn lichaam drong. Maar de goeroe droeg een bizonder soort amulet (bekom bekom) van geweldige kracht, en zag zich daardoor in staat nog een uur of vier naar boven te wandelen, tot aan den Batoe Pikpik. Hier echter ontdeed een onhandig vriend, begaan met zijn treurigen toestand en niet bekend met den aard van de bekom bekom, hem van het vrij zwaar schijnende amulet, wat tengevolge had dat de goeroe aanstonds den geest gaf. Sedert woont hij in den Batoe Pikpik en waarschuwt zoo noodig de omliggende koetas, waarvan de hoofden ook tot de marga Karo karo Kemit behooren, tegen naderend onheil. Hierbij is niet te vergeten dat de voornaamste der door hem beschermde dorpen Sala Boelan en Boeloe Auer steeds met elkaâr over hoop liggen of liever lagen. Slechts als zij den Batoe Pikpik huldigen, vergeten zij voor eenigen tijd hunne grieven en brengen samen hunne offers. 
In dezelfde kampong Sala Boelan heeft men een ander heiligdom, een zoogenaamden pagar laboelaboe. Uiterlijk ziet men niets dan een vrij kleinen steen omgeven door vier stukken hout. Daaronder schijnt echter iets geheimzinnigs begraven te zijn, iets van ijzer, maar iets bepaalds wist niemand mij te vertellen.

Vóór de krijgers ten oorlog gaan, offeren zij daar sirih met het doel onkwetsbaar te worden.

Deze pagar laboelaboe wordt nu en dan op eigenaardige wijze vereerd. Er wordt gedanst door zeven vrouwen, in eene waarvan de geest van de pagar laboelaboe vaart. Namens dien geest vraagt de opgewonden vrouw dan te eten en verorbert eene gansche kip, dat maal met vele teugen palmwijn besproeiende. Intusschen loopen hare zes volgelingen, ook min of meer bezeten, overal om en onder de huizen rond om kippeneieren te zoeken, die zij dadelijk opeten. Is het feest afgeloopen en komt de hoofdpersoon weêr tot bezinning, dan is haar eerste werk om eten en drinken te vragen, wel een bewijs dat niet zij, maar wel de geest vian de pagar laboelaboe kip en palmwijn verteerde. Dit heiligdom zal dan ook ongetwijfeld wel op dergelijke wijze als de pengoeloebalang's zijn vervaardigd en de een of andere bégoe tot schnilplaats dienen.

Hierboven vermeldde ik ter loops reeds enkele andere voorwerpen, die met de godsdienstige beprippen der Karo-Bataks in nauw verband staan, en waaraan voor hen het denkbeeld van tooverkracht is verbonden. Ik noemde daar verschillende soorten van tooverstokken (tonggal penaloean, tongkat maléhat of malaékat, perang djalan), verder perminakan, pagar en pendapattan, waaraan ik nog als eveneens zeer bekend de ikal kan toevoegen. De tooverstokken bestaan steeds ten deele uit beeldwerk, min of meer ruw in het hout uitgesneden, en allerlei figuren van menschen en dieren (paarden, honden, slangen, hagedissen, enz.) voorstellende. Rondom het boveneinde is soms een krans van lauweren aangebracht. Een vast model wordt bij de vervaardiging niet gevolgd, en zoo komen op verschillende stokken veelal ook verschillende figuren voor, die dientengevolge dror de goeroes met min of meer van elkaâr afwijkende verhalen worden toegelicht. Het algemeen geldende beginsel dat slechts het innig verbinden van eenig voorwerp met de ziel van den een of anderen afgestorvene aan dat voorwerp zijne tooverwijding geeft, is ook voor de tooverstokken van kracht. Soms, wij zullen het zien bij het verhaal van den tonggal penaloean van Goeroe Beleilei, is voor het tot stand brengen van dat verband geenerlei 
kunstbewerking noodig, maar in verreweg de meeste gevallen is het hier ook weêr de kostbare poepoek die de geheimzinnige staven hunne macht geeft. Die poepoek wordt of ergens in eene kleine holte aangebracht, of het beeldwerk wordt er meê bestreken. De tooverstaven worden bij allerlei godsdienstige plechtigheden gebruikt, doch vooral bij het uitbannen en verdrijven van nijdige bégoe's en andere geesten.

Als voorbeeld knnnen hier de formaliteiten strekken, gebruikelijk om het gevreesde toovermiddel van het penoeroêni tegen te gaan.

Wil namelijk iemand de bewoners eener koeta kwaad, of heeft hij er belang bij twist onder hen te stoken, zoo laat hị door een knappen goeroe een toovermiddel maken, waarvan de kop en hals van een rooden haan, of van een hond, omwikkeld met brandnetels het hoofdbestanddeel uitmaken, en laat het door dien goeroe des nachts heimelijk in de karebangan (paggerdeur) der koeta begraven. Heeft men eene veete tegen een bizonder persoon, dan wordt het onheilbrengend preparaat onder de trap zijner woning begraven.

Bestaat er vermoeden dat zulke kwade kunsten in eenig dorp in practijk zijn gebracht, dan wordt een goeroe geroepen om de orde te brengen. De man brengt zijne tongkat malaékat mede. In het holle van den nacht gaat hij dan daarmeê rond en legt beurtelings vóór elke tangga (trap van een huis) alsmede in de karebangan een ei neer met wat fijngestampte beras. $\mathrm{Nu}$ is het de kunst dit ei onder het aanroepen der débata in drie stooten te verpletteren. Tukt dit niet, dan wordt het nog eens beproefd, nadat de tongkat met sirih is ingesmeerd. Heeft ook dan de stoot nog geen resultaat, dan ziet het er voor de bewoners van het huis slecht uit. Telkens wanneer een ei verbrijzeld is, worden de overblijfsels verbrand en wordt er een geweerschot gelost. $\mathrm{Na}$ afloop der plechtigheid slacht men honden en kippen en richt daarvan een maaltijd aan.

In die koetas, welke met hare buren in geene goede verstandhouding leven, wordt veelal bij wijze van voorzorgsmaatregel eens in het jaar tot de plechtigheid van het ngoelak overgegaan.

Het onderscheid tusschen de tonggal penaloean en de tongkat malaékat ligt daarin dat de eerste in haar geheel uit één stuk hout is gesneden, terwijl de tweede slechts kort is en aan een langeren stok bevestigd wordt. De perang djalan is ook kort, maar wordt ook zonder verlengstuk gebruikt. De ondereinden der tooverstokken zijn bijna altijd spits, waardoor men ze gemakkelijk in den grond kan planten. Dat zij als "Kriegspaniere" zouden worden gebruikt komt mij zeer onwaarschijnlijk voor. Wel gebruikt men in den oorlog 
tot afwering der kogels een soort vlaggen (pandji); bamboezen stokken met een lap witte of roode stof, waarop eenige Bataksche letterteekens zijn aangebracht.

Zooals ook Dr. Hagen vermeldt, beweren de goeroes dat de stem der aan den tooverstok verbonden bégoe zich soms duidelijk in dat voorwerp laat hooren. Hetzelfde geldt trouwens evenzeer van de pengoeloebalang en perminakan.

Deze laatste bestaan meest uit potjes van aardewerk, waarin zich poepoek bevindt en die gesloten worden door houten stoppen, waarin weder allerlei figuren zijn uitgesneden. Veelal springt het beeld van een paard het meest in het oog, doch ook menschenfiguren ontbreken niet, soms van mannen en vrouwen die bezig zijn den coïtus uit te oefenen. Deze laatste beeldjes zijn wel de meest toepasselijke, want de perminakan dient vooral om den eigenaar de gunsten van het schoone geslacht te verzekeren. Echter kan de daarin aanwezige poepoek, waarvan de overblijfselen eener in het kraambed gestorven vrouw het hoofdbestanddeel behooren uit te maken, ook voor andere doeleinden worden gebezigd, bijvoorbeeld als geneesmiddel tegen sommige vergiften. Evenals aan de pengoeloebalang en tooverstokken worden nu en dan ook aan de perminakan overigens vrij onbeteekenende offers gebracht.

Vrij geregeld van voedsel voorzien worden ook de pagar, bij wier samenstelling eveneens de onvermijdelijke poepoek hare diensten bewijst. Het daarmeê bereide mengsel wordt in een bamboezen kokertje, of meestal in een aarden kopje bewaard, en ergens aan den wand van het huis opgehangen. De pagar beschermt tegen allerlei kwade practijken en tooverkunsten als het penoeroeni, enz. en eveneens tegen vergiften. Heeft de eigenaar vermoeden dat een heimelijke vijand hem eene poets wilde spelen, dan wordt een weinig van de pagar in water opgelost, en worden de spijzen met dat smakelijke sausje overgoten.

Het voedsel, waarop men de pagar gewoonlijk eens in de drie of vier maanden onthaalt, bestaat uit een deel van de ingewanden eener kip, vermengd met Spaansche peper en kruiden. Lieden die op reis gaan naar streken, welke als rijk aan giftmengers bekend staan, nemen zoo mogelijk wat pagar als voorbehoedmiddel meê.

Bij de pendapattan krijgen wij met eigentlijke amuletten te doen. Onder deze benaming verstaat de Batak zekere voorwerpen als steentjes, stukjes rotan, vruchten, enz., die hetzij om hun voorkomen, hetzij om de eigenaardige omstandigheden waaronder zij 
worden gevonden, zijn oog en zijne verbeelding op bizondere wijze treflen. Bij voorbeeld, een vader heeft zijn kind begraven en natuurlijk het graf goed schoon gemaakt. Den volgenden dag bezoekt hij de plaats en vindt op het graf een steentje of zoo iets liggen, waarvan hij niet begrijpt hoe het er is gekomen. Dit makt een sterken indruk op hem, hij gelooft bier met eene pendapattan te doen te hebben, neemt het steentje meê en toont het aan een goeroe, die verklaart of de man al dan niet juist heeft geoordeeld. Ts dit wèl geval, dan wordt de pendapattan door den vinder met de uiterste zorg bewaard en als een krachtige talisman beschouwd. Men mag echter niet verzuimen het voorwerp op gezette tijden met limoensap te wasschen (oeras).

1kal eindelijk zijn armbanden, vervaardigd uit de lippen van verslagen vijanden die gedroogd en met draad omwonden worden. Zij maken den eigenaar moedig in den strijd, en verzekeren hem, in geval hij gewond mocht worden, een oogenblikkelijken dood, waardoor hị in de geestenwereld recht krijgt op den rang van matei sadawari.

In dit opstel heb ik herhaaldelijk over de goeroes gesproken. Men moet echter niet meenen dat deze priester-toovenaars veel van het aanzien en den invloed bezitten die de priesterstand zich in christelijke en Mohammedaansche landen heeft weten te verwerven. Wat daaraan in de eerste plaats in den weg. staat is, dat dezen geneesheeren alle kastengeest ontbreekt en ze elkaâr niet als bondgenooten maar uitsluitend als concurrenten beschouwen. Minder wegens de financieële zijde der kwestie dan wel uit eerzucht zijn zij in de hoogste mate naijverig op elkaârs kunde en cliëntele. Van onderdeelen hunner wetenschap willen ze tegen behoorlijke vergoeding dikwijls den een en ander wel op de hoogte brengen, doch de fijnheden hunner kunst zorgen zij zooveel mogelijk in de eigen familie te bewaren, zoodat bij den dood van een goeroe meestal een zijner zonen of een andere door den overledene zorgvuldig onderrichte bloedverwant in zijne functies treedt.

Ontbreekt dus alle esprit de corps bij de groote mannelijke goeroes, deze waarheid geldt eveneens voor hunne vrouwelijke vakgenooten, die als goeroe sibaso bekend zijn, en wier kracht vooral ligt in het oproepen van bégoe's en het optreden als mediums tusschen deze en de levenden. Hare verdiensten zijn meestal uiterst bescheiden en zelfs in verhouding tot de moeite die zij zich moeten geven met zingen, schreeuwen, dansen en het zich eten van indigesties, uiterst laag te noemen. Ik zag dergelijke vrouwen heele bossen sirihbladeren. 
verslinden. Of zij voor zich zelven eerlijk overtuigd zijn onder den invloed der geesten te handelen, is eene vraag die ik niet waag te beantwoorden.

De mannelijke goeroes leggen zich meer toe op het vervaardigen van genees- en toovermiddelen, van vergiften, enz;; bij belangrijke plechtigheden wordt hunne hulp ingeroepen, en in vele gevallen wordt hun raad op hoogen prijs gesteld. Zij weten de gevolgen van kwade droomen te voorkomen, zij kunnen de beste namen voor kinderen opgeven en hebben veel verstand van goede en slechte dagen, zoodat men niet licht tot eenige belangrijke handeling zal overgaan zonder den goeroe het meest geschikte tijdstip te hebben doen aanwijzen.

Hunne verdiensten zijn veel beter dan die hunner vrouwelijke collegas, en er gat dikwijls een groote roep van hen uit, hetzij ten goede, hetzij ten kwade. Terwijl bijvoorbeeld de goeroe Beleilei algemeen werd geroemd, en van heinde en ver bij zware ziektegevallen werd geroepen, overleed er dit jaar in het onder Tandjong Moeda ressorteerende Roemah Rih een goeroe die algemeen als giftmenger was gevreesd. Bij een bezoek, door mij aan die koeta gebracht, was het eerste werk mijner talrijke, uit andere streken af kom. stige Bataksche volgelingen dien goeroe hunne opwachting te maken en hem sirih aan te bieden, ten einde hem door die beleefdheid gunstig voor hen te stemmen. De man zat onder een afdakje en hield den heelen dag audientie. Hij was een vuile kerel, reeds grijs, lang van gestalte en met een buik; hij leed erg aan asthma en spoog voortdurend rondom zich, zoodat hij een tamelijk walgelijken indruk maakte. Toen ik den volgenden dag verder trok, bleef een mijnier lieden heimelijk achter om zich door den wijzen man gedurende eenige dagen les in de zwarte kunst te doen geven.

De goeroe Beleilei was bezitter van een bizonder fraaien stok (tonggal penaloean) waarvan hij voor geen geld ter wereld afstand wilde doen, doch waaromtrent hij mij het volgende verhaal deed.

De moeder van den hoofdpersoon dezer geschiedenis heette Siberoe Tapian Toenggal Penaloean Djati, en stamde door de vorsten van Poerba af van Toean Benoewa Katji. Zij was gehuwd met den radja van Irissen.

Dit huwelijk kon tot de gelukkige worden gerekend en zou nog nog gelukkiger zijn geweest, ware de oudervreugd niet jaren lang aan de beide echtgenooten onthouden.

Op zekeren dag kwam de herder, die met het toezicht op 's radjas talrijke geiten was belast, zijn heer melden dat een beroemde goeroe, 
Goeroe Pakpak Bertandang geheeten, juist aan den buitenkant van het dorp voorbijging. Vol eerbied voor dien wijzen man riep radja Irissen (Poerba en Irissen waren, zooals ik reeds vroeger vermeldde, twee der fabelachtige rijken waarheen de uiteinden der besimaléla wijzen) zijn anakberoe-senina (mindere hoofden die in zekere familieverhouding tot den radja staan) alsmede een aantal zijner onderdanen bijeen, en zocht met hen den goeroe op, wien hij als huldebewijs eene geit, eenige matten en siri aanbood. Nadat de eerste begroetingen hadden plaats gehad, nam hij den heiligen man meê naar huis en liet daar door zijne vrouw een heerlijken maaltijd voor hem aanrichten.

Spoedig kwam het gesprek op de kinderloosheid van het echtpaar, dat in dit opzicht reeds geleerd scheen te hebben in het onvermijdelijke te berusten. Peinzend keek de goeroe voor zich, tot hij plotseling zeide:

"Neem een stuk dood hout en een stuk bamboe. Plant die in "den bodem, en wanneer zij in vier dagen niet bloeien, moogt ge "me een kwakzalver noemen."

De radja deed, zooals hem gezegd was, en ziet, binnen den bepaalden tijd sproten frissche uitloopers uit de uitgedroogde stokken.

Dit sterke stukje gaf radja Irissen moed den toovenaar te vragen of hij hem misschien niet aan wettige kinderen zou kunnen helpen. En inderdaad, de goeroe wist er wel raad op. Hij nam zijn gastheer en diens echtgenoote meê naar de badplaats en liet hen daar drie sirihbladeren ofteren, waarna hij hen namens de débata meêdeelde, dat hen vooruit de inwilliging was toegestaan van een door hen te doen verzoek. Vol vreugde wenschten zij zich een zoon. Nu viel de vrouw neer, als door den bliksem getroffen, doch de goeroe deed haar weêr bijkomen. Allen wieschen zich nu plechtig de haren, en keerde daarop naar de koeta terug. Vijf maanden later was Siberoe Tapian Toenggal Penaloean zwanger.

Toen de tijd der bevalling naderde, liet zich in den buik der vorstin een zacht gezang hooren. Terstond liet men den goeroe roepen en deze noodigde den jeugdigen zanger vriendelijk voor den dag te willen komen.

Doch het knaapje bleek geenszins genegen aan dat verzoek dadelijk te voldoen. Integendeel eischte hij zeer stellig de voorafgaande vervulling van drie voorwaarden :

10. moest men de zalf pagar bindoeboelan gereed maken;

2o. verlangde hij dat er te Poerba ezne pantangan (op één paal rustend huisje) werd gereed gemakt voor den goeroe; 
3o. diende zijn naam vooruit te worden bepaald.

Men haastte zich deze drie wenschen te vervullen en bepaalde dat het vroegwijze ventje Toean Adji Donda Kateikoeten zou heeten.

Weldra volgde nu de bevalling, maar ziet, nanwelijks was het kindje te voorschijn gekomen of reeds was, het door een gat in den vloer verdwenen. Daar het nacht was, nam men eene lamp en ging zoeken.

Vergeefsche moeite; beneden het huis was niets van Adji Donda te bespeuren. Doch de goeroe $\mathrm{kreeg}$ een ingeving en snelde naar Poerba, waar het bleek dat de jongeheer zijn intrek in de pantangan had genomen.

Goeroe Pakpak Bertandang noodigde hem uit naar beneden te komen, daar zijne ouders van verlangen brandden hem eens wat nader te bekijken. Doch Adji Donda bleef zich een bizonder ongezeggelijke zuigeling toonen. Hij verklaarde daarboven zeer op zijn gemak te zijn en niet naar beneden te zullen komen voordat zijne ouders hem hunne opwachting hadden gemaakt, waarbij zij voor hem meê moesten brengen een karbouw, twaalf gantangs beras, drie hanen, veel spaansche peper, veel sagoeweer, enz., en zich verder moesten doen vergezellen door drie pengoêwel (muziekkorpsen).

De goeroe waagde bescheidenlijk op te merken dat Adji Donda's moeder, als zijnde onlangs bevallen, moeilijk naar Poerba zou kunnen wandelen, maar de knaap antwoordde dat dit geen bezwaar behoefde te zijn. Hij zou den goeroe eene gekauwde sirihpruim meêgeven, die een uitstekend geneesmiddel zou blijken. En hij jokte niet, want zoodra de kraamvrouw het pruimpje had genuttigd, was zij weêr zoo fleurig als een roos.

Den volgenden dag trok Radja Irissen met een talrijk gevolg naar Poerba, de door zijn zoon verlangde geschenken meêvoerende. Onder de pantangan werd een offer gebracht van een rooden, een witten en een gelen haan.

Maar ook met dat offer was het niet richtig, want hoewel de halzen der hanen behoorlijk waren doorgesneden, bleken de dieren nog kracht te hebben naar de tamelijk ver verwijderde rivier te vliegen om eerst daarna onder de pantangan te komen sterven.

"Wel heb ik van mijn leven!" zeide de goeroe. "Wat een malle "beesteu. Snapt gij er iets van, Adji Donda?"

Om Adji Donda's lippen speelde een spottend lachje.

"En dat wil een goeroe heeten," lachte hij. "Begrijpt ge niet "dat de débatas ons willen waarschuwen, dat zij ons als 't ware "toeroepen : «djalak tandang belajer, poelak mendjadi poeling, poeling 
"mendjadi poelak, ikan matei di deleng, imbau matei di laoet" (d i. "kippen gaan uit varen, moesangs worden valken, valken worden "moesangs, visschen sterven in 't gebergte, zwarte apen sterven in "de zee). Kortom, het is een slecht teeken, een tecken van de "wisselvalligheden des levens, bewijzende dat alles verkeerd zal "gaan. Wie rijk is zal arm worden, en wie arm is rijk."

Het spreekt van zelf dat deze voorspelling de ouders van den jonggeborene slechts matig beviel. Doch zij makten bonne mine at mauvais jeu, lieten de gendangs en de verdere inuzickinstrumenten bespelen; den karbouw slachten en zijn vleesch cvenals de metgebrachte rijst, enz. bereiden.

Dit beviel Adji Donda, hij kwan naar beneden en begon terstond met veel hartstocht een "pas seul " te dansen, en op dozs bij de Bataks gebruikelijke wijze zijne ouders te begroeten. Bpoedig waren ook de omstanders door danslust aanzestoken, en werd het tandakken algemeen.

Men hield niet op voor het eten geresd was. Doch de fecstgenooten zouden daar niet veel genoegen van hebben, want zonder eenige komplimenten viel Adji Donda op het diner aan, waarvan hij niets dan leege schotels en afgekloven botten overliet.

Vergeefs had zijn vader beproefd aan dit overdreven smullen een einde te maken. Er schoot voor Radja Irissen, die zich tegenover zijne gasten uiterst beschaamd gevoelde, niets over dan hen meê naar huis te nemen, en daar een nieuwen maaltijd te laten aanrichten. Van de twee daarvoor geslachte karkouwen werd er nog een door Adji Donda verslonden.

Het knaapje ging voort op dien weg en nuttigde bij elken maaltijd een karbouw, zoodat hij heel wat vlugger groeide dan met gewone kinderen het geval is. Doch op den duur was ook het aanzienlijkste Bataksche fortuin niet tegen zulke pretenties bestand. Radja Irissen werd armer en armer en zag den bedelstaf in het verschiet.

Op een goeden dag eindelijk had zijne vrees voor de toekomst de overhand over zijne vaderliefde en berispte hij Adji Donda over zijne verregaande vraatzucht. Maar de jongeling nam met de vaderlijke vermaningen geen genoegen.

" Ik moet zeggen dat ik u niet erg consequent vind ", zeide hij met al de gemeenzaamheid die de houding van Bataksche kinderen tegenover hunne ouders kenmerkt. " Eerst hebt gij om mij gebeden "en gesmeekt, en nu ik er ben, is het $u$ te veel mij te eten te 
"geven. Welaan, ik zal zien er iets op te vinden. Wil intusschen zoo "goed zijn al mijne verwanten bijeen te roepen".

Eenige dagen later vergaderde werkelijk de familieraad, waarin Adji Donda, na aan zijne ouders op weemoedigen toon hunne schrielheid te hebben verweten, meêdeelde dat hij het ouderlijke huis ging verlaten, en in het vervolg door de jacht in zijn onderhoud zou voorzien, wanneer men hem ten minste daartoe in staat wilde stellen door zeven honden voor hem te koopen.

Zulks geschiedde, en nadat elk der verwanten Adji Donda nog eens voor het laatst siri had aangeboden, trok hij met zijne blaffende viervoeters naar de Karangan (oorspronkelijk woud) Limboeraja, waar hij een olifant en een hert ving, en daarvan een paar dagen leetde. Vervolgens trok hij verder naar den Deleng (berg) Mauléaulé.

Hier ontmoette hij in het diepste van het woud weldra een allerliefst meisje, dat hem met belangstelling vroeg waar hij van daan kwam. Voorzoover zij wist, was hier nog nooit een menschelijk wezen gekomen. De jongeling stortte zijn hart voor zijne schoone ondervraagster uit, zijn verhaal besluitende met de tragische woorden: "mijne ouders hebben mij verstooten en voortaan kan ik slechts "tijgers en slangen als mijne bloedverwanten beschouwen."

Diep medelijden teekende zich op de lieve trekken der jonkvrouw, en blozende stelde zij hem voor van de verwantschap met die akelige dieren af te zien en voortaan hare ouders als de zijne te beschouweu. $\mathrm{Nu}$ gingen zij over tot het ertoetoer (het vragen naar elkanders marga dat bij de Bataks elke kennismaking inleidt) wat tot bevredigende uitkomsten leidde, daar het bleek dat zij tot verschillende marga's behoorden, en hunne verhouding dus geene platonische behoefde te blijven.

Toch aarzelde Adji Donda het aanbod der jonge dame aan te nemen. Zij was wel erg lief en mooi, maar soms leek zij in eens een boomtak of een steen, zoodat hij zich de oogen moest uitwrijven om zich te overtuigen dat toch werkelijk een wezen van vleesch en bloed voor hem stond.

Rondweg kwam hij voor die zonderlinge gewaarwording uit. Maar het meisje verzekerde hem schertsende, dat hij zich niet ongerust behoefde te maken en alles op eene bevredigende wijze zou worden opgehelderd, zoodra hij zich door eene vaste belofte aan haar zou hebben verbonden.

Adji Donda had een gevoelig hart, weinig opgewassen tegen de toovermacht der schoonheid. Hij eindigde dus met zich over te geven 
en zich zonder verzet naar haren grootvader te laten geleiden, die hunne geloften zou bezegelen. Deze machtige hantoe heette Radja Poldang di Bégoe, welken naam hịj daaraan dankte dat steeds een krans van poldangbladeren zijn eerwaardig hoofd versierde.

$\mathrm{Hij}$ makte eene bamboeën van eene pasgeboren kip en de noodige kruiden, en terwijl hịj den geesten dat offer aanbood, liet hij de geliefden zweren elkaâr trouw te zullen blịjven.

Nauwelijks was die eed afgelegd, of eensklaps zag Adji Donda rondom zich een fraaie koeta, en vóór hem zijne Dulcinea bezig met weven. Hij had zich aan niemand minder verloofd dan an Si Goeroe Maniktik doeng Seroeparoepa, dochter van deu vorst der orang boenian.

Zoo spoedig mogelijk worden nu de jongelieden vereenigd in een echt, die alle kansen op geluk scheen aan te bieden.

Maar helaas, de verbazende eetlust van Adji Donda stond hem ook in deze nieuwe phase zijns levens in den weg. Karbouwen en ruuderen, varkens en geiten verdwenen in eindelooze reeksen in de magen van den jongen vorst en van zijne zeven honden. De orang boenian begonnen verlegen te worden. Onze held wist er niets anders op dan maar weêr de wildernis in te trekken om zich daar door de jacht voedsel te verschaffen. Zịne gemalin had hiertegen echter vele bezwaren. In het naburige woud toch huisde een wonderschoon meisje, Si Beroe Tapian Manoeassan, nichtje van Adji Donda's echtgenoote, en dochter van den vorst van Daksina.

Doch Adji Donda lachte om deze ijverzucht en toog den volgenden morgen ter jacht. Door duistere voorgevoelens geplaagd, achtte Si Goeroe Maniktik het oogenblik gekomen om van hare hoedanigheden van orang boenian partij te trekken. In een ommezien had zij zich onzichtbaar gemaakt en was haren echtgenoot gevolgd.

De jacht voerde den laatste in de buurt van Daksina. Plotseling was het als ging de zon op in het donkere bosch, en toen de jonge man opkeek, zag hij eene maagd van onbeschrijfelijke schoonheid voor zich staan. Zij sprak hem vriendelijk aan, en Adji Donda, die met het hart op de tong liep, wist niets beters te doen dan haar terstond deelgenoote te maken van al zijne rampen en tegenspoeden. Hierop volgde het ertoetoer, waaruit bleek hoe Adji Donda ook hier aan zijn hartstocht geen geweld zou behoeven aan te doen. Daar hij opmerkte hoe nu en dan eene wolk over het voorhoofd der jonkvrouw gleed, vroeg hij belangstellend of zij verdriet had.

"Mijne moeder is al sinds een jaar erg ziek, zij kan noch leven, noch sterven." 
Adja Donda wist hier gelukkig raad op, en gaf het schoone kind een siripruimpje voor de zieke moeder meê. Onder dankbetuigingen nam Beroe Tapi Manoeassan afscheid en spoedde zich naar Daksina, waar hare moeder na het nuttigen van het pruimpje dadelijk beter werd.

De oude vrouw verlangde zeer haren redder te aanschouwen, en gelastte hare dochter den jongen man overal te zoeken: eene taak welke de jonkvrouw zonder eenigen tegenzin op zich scheen te nemen. Gelukkig behoefde zij niet ver te gaan, want eene sterke magneetkracht trok Adji Donda naar Daksina, en zoo ontmoette zij hem reeds den volgenden dag op de ladang. Zij verzocht hem meê te gaan, en hoewel hij, denkende aan het weinig vriendelijke beeld van Radja Poldang di Bégoe, en aan zijn door dien ouden heer bezegelden eed begon met tegen te stribbelen, hielden zijne gemoedsbezwaren toch geen stand, toen Beroe Tapi Manoeassan hem hare liefde bekende, en beloofde hem voor altijd te zullen toebehooren. Hij riep dus zijne honden en volgde de jonkvrouw naar Daksina, zijne onzichtbare gemalin, die hem steeds was gevolgd, aan de bitterste vertwijfeling ten prooi latende. Nog denzelfden dag zag zich Adji Donda net zijne nieuwe geliefde in den echt verbonden.

Doch ook hier droegen de rozen weêr de oude doornen. Adji Donda en zijne honden waren onverzadelijker dan ooit en met den veestapel van Daksina ging het denzelfden weg op als met dien van de orangboenian-kota.

Hij besloot dus opnieuw zijne toevlucht tot de jacht te nemen.

"Doe het niet", waarschuwde Beroe Tapi Manoeassan, "ge hebt "uwe eerste vrouw leelijk in den steek gelaten, en haar grootvader, "Radja Poldang di Bégoe, zal zeker pogen zich op $\mathrm{u}$ te wreken. "Mocht ge bij ongeluk zijn gebied betreden, dan zijt ge verloren "

Doch de honger dwong, en zoo ging Adji Donda er toch op uit. Zijne vrouw echter verzon een list om hem op veilig gebied te houden. $Z_{i j}$ had het vermogen eene dierengestalte aan te nemen, en volgde nu haren man tot even buiten de koeta, waar zij zich veranderde in een bernawit (een klein soort roofdier). In die gedaante wist zij de aandacht der honden tot zich te trekken, en leidde hen nu den heelen dag in de omstreken van Daksina rond.

Eerst toen de avond viel, onttrok zij zich aan de vervolging en keerde snel naar Daksina terug, onder weg hare menschelijke gedaante weêr aannemende.

Een oogenblik later verscheen ook Adji Donda, verstoord over het weinige gevolg der jacht. dat hịj vooral daaraan toeschreef dat 
de honden dien morgen niet genoeg te eten hadden gebad. Den volgenden morgen kregen zij dus eene dubbele portie, en volgden daarop hun meester naar de wildernis. Beroe Tapi Manoeassan herhaalde het spelletje van den vorigen dag, maar het bekwam haar slecht, want de honden waren haar ditmaal te sterk en joegen haar naar den berg Mauléaulé. Doodmoede beklom zij hier een' boom, ten einde te ontkomen aan het gevaar verscheurd te worden, en om tijd te vinden hare ware gestalte weêr aan te nemen. Vol verbazing zag Adji Donda in plaats van de zoo heet vervolgde bernawit zijn jong vrouwtje daar boven zitten. Toornig klom hị naar boven om haar door eene kleine echtelijke tuchtiging voor hare fopperijen te straflen.

Doch plotseling voelden zoowel de jonge man als Beroe Tapi Manoeassan en de zeven honden zich door eene onzichtbare macht aan humne plaatsen gekluisterd. De reden zou hen spoedig onthuld worden, want Si Goeroe Maniktik en haar grootvader Radja Poldang di Bégoe traden uit het duisterste deel van het woud te voorschijn.

Zonder veel omslag werd aan Adji Donda meêgedeeld dat hij met zijn geheel gevolg aan de wraak zijner eerste gemalin was overgeleverd. Het lot dat hem, zijne vrouw en honden wachtte, was tot hout te verstijven en samen te groeien met den boom, dien zij ter kwader ure hadden beklommen. En zoo geschiedde het. Zịj verlamden, verdorden en verschrompelden en weldra waren zij nauwelijks meer te onderscheiden van den knobbeligen stam. Slechts een gedempt geween dat nu en dan de stilte van het woud verbrak, bewees dat in die op verwaarloosd beeldwerk gelijkende gestalten nog zielen huisden.

Mettertijd echter werd door dit droevig gekerm het hart van $\mathrm{Si}$ Goeroe Maniktik toch eenigszins verzacht. Zij riep de tamilieleden harer slachtoffers, alsmede Goeroe Pakpak Bertandang bijeen, en makte hen met het lot der beide menschen bekend. Tevens beloofde zij hen nog eenmaal voor enkele uren weer in het leven terug te zullen roepen om hen zoo de gelegenheid te schenken van hunne verwanten afscheid te nemen. Onder hevig geween trokken daarop allen naar den berg Mauléaulé, spijzen meenemende en boemboeën.

Si Goeroe Maniktik hield hare belofte. Voor het laatst keerden de gelieven nog eens tot hun volle bewustzijn terug en nuttigden eenige spijzen. Veel eer deden zij echter den maaltijd niet aan, want zelfs Adji Donda's eetlust was tegen de slagen van zulk een noodlot niet bestand.

Toen Goeroe Maniktik op het punt stond de ongelukkigen weder te doen verstijven, richtte Adji Donda het woord nog eenmaal tot 
zijne moeder, en verweet haar dat zij, die voor zijne geboorte zoo ondankbaar was gebleken, de schuld droeg van al zijne rampen.

"Maar", zoo vervolgde hij, "ik wil kwaad met goed vergelden. "Neem mijjne verstijfde gestalte meê naar uwe koeta en steeds zal " ik $\mathrm{u}$ behulpzaam zijn bij het terugroepen van tendis en het ver"drijven van bégoe's. Behalve voor die doeleinden moogt gij mij "echter nimmer meer een huis laten betreden.

"Al kan ik dan ook niet naar de kust gaan om zout voor u te "halen, en al zal mijne vrouw nooit voor u kunnen spinnen, toch "zal ik zorgen dat zout en garen in uwe woning nimmer ontbreken."

Goeroe Pakpak Bertandang begreep den zin dier woorden. Hij kapte den boom voorzichtig om, ontdeed hem van takken en bladeren en verkreeg zoo van zelf een fraaien tooverstok, die eene buitengewone kracht bleek te bezitten en zoo inderdaad den eigenaar het zout en het garen verschafte, waarmeê menigmaal de hulp der goeroes wordt betaald. Nog steeds wordt de tonggal penaloean, in voldoening aan Adji Donda's laatsten wensch buitenshuis bewaard. Verlangt men den stok te gebruiken, zoo wordt hem eerst sirih geofferd. De eigenaar verzekerde mij met den grootsten nadruk, dat zijn tonggal zich meer dan eens door eigen beweegkracht aan brandgevaar had onttrokken.

Indien ik met dit verhaal mijn opstel eindig, is het allerminst omdat het onderwerp door de voorafgaande mededeelingen is uitgeput. Tal van gebruiken en plechtigheden die met het godsdienstig leven der Karo's in het nauwste verband staan, zijn door mij zelfs niet aangeroerd. Ik noem hier slechts den eed; al wat de behandeling der dooden betreft; de in het oog der Bataks zoo bebelangrijke kwestie der goede en kwade droomen; en der middelen waardoor men den boozen invloed der laatste kan tegengaan, enz., enz.

Dat deze onvolledigheid niet de eenige fout in dit opstel zal wezen, daarvan ben ik volkomen overtuigd. Op verschillende zaken heb ik ongetwijfeld een minder juist, of liever een slechts zeer plaatselijk juist licht laten schijnen.

Dit laatste levert trouwens de groote moeielijkheid op bij bijna alle ethnografische onderzoekingen. In weinig van elkaâr verwijderde streken vindt men menigmaal op allerlei gebied belangrijke afwijkingen; zoodat bijna alle mededeelingen ter zake slechts in een algemeenen zin juist kunnen zijn, en men zelfs daarbij nog licht in eene goede zifting der bijeengebrachte bouwstoflen kan falen. Ik moet dan ook, om misverstand te voorkomen, nog eens uitdrukkelijk 
verklaren, dat mijne aanteekeningen zoo goed als uitsluitend onder de Doesoen-Bataks (Karo's) van Deli zijn verzameld. Met het oog op de zeer nauwe verwantschap tot en de steeds ijverig onderhouden betrekkingeu met de onafhankelijke Karo's, kan men wel is waar veilig aannemen dat wat voor den een geldt in hoofdzaak ook voor den ander waarheid zal bevatteu, maar toch zijn afwijkingen op hoofdpunten niet geheel onmogelijk, en in sommige onderdeelen zelfs waarschijnlijk.

Hetzelfde geldt, maar in veel sterkere mate voor de naburige Timor-Bataks, die een geheel ander dialect spreken, en ook in volkskarakter, enz. zeer van de Karo's verschillen.

Mogen latere onderzoekers op dit gebied het mij dus niet euvel duiden, wanneer zij in sommige opzichten tot andere gevolgtrekking zullen kowen dan waartoe ik mocht geraken.

Medan, 15 November 1891. 